\title{
Environmental Management \\ Can artificial ecosystems enhance local biodiversity? The case of a constructed wetland in a Mediterranean urban context \\ --Manuscript Draft--
}

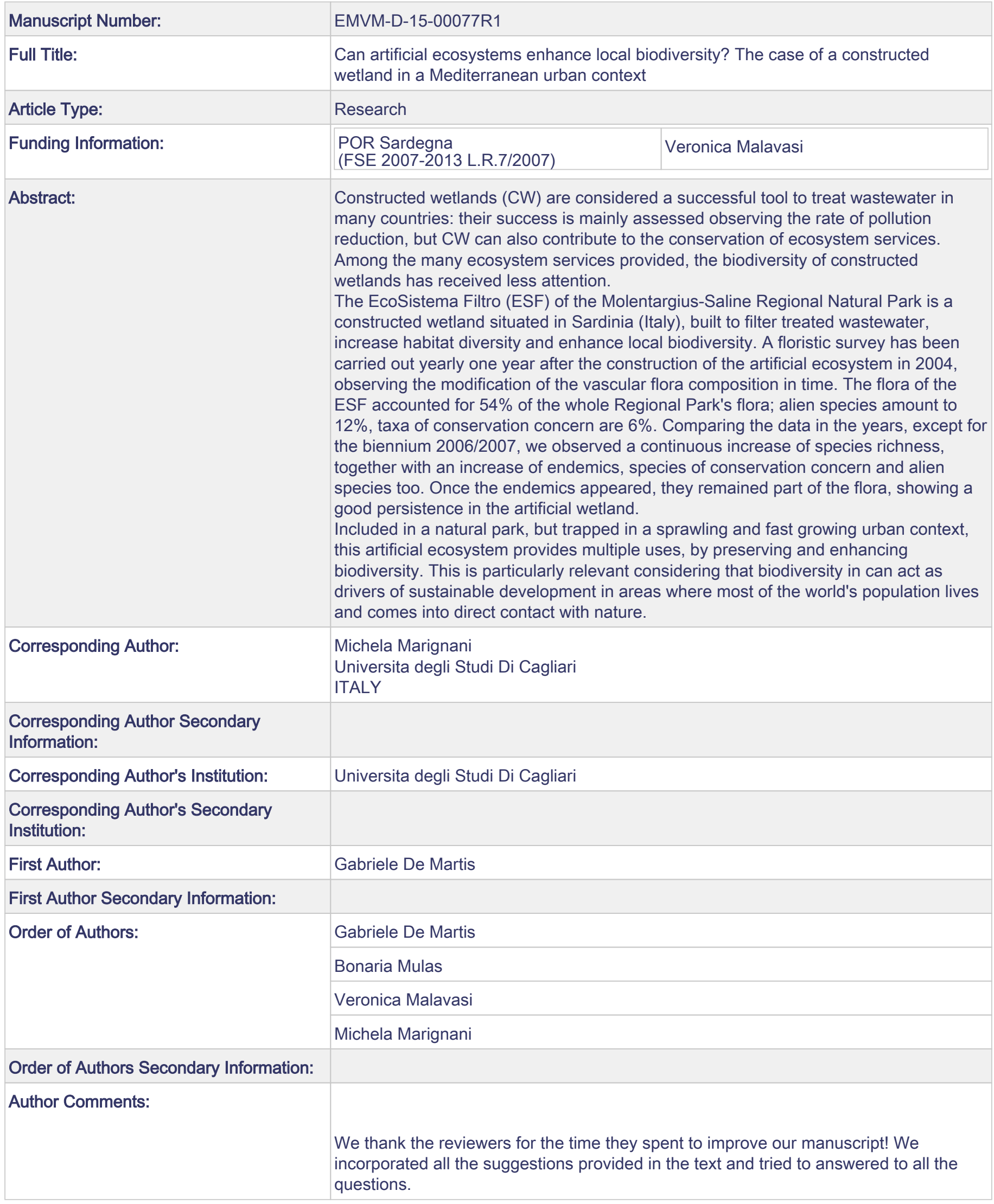


Can artificial ecosystems enhance local biodiversity? The case of a constructed wetland in a Mediterranean urban context

\begin{abstract}
Constructed wetlands $(\mathrm{CW})$ are considered a successful tool to treat wastewater in many countries:

their success is mainly assessed observing the rate of pollution reduction, but $\mathrm{CW}$ can also contribute to the conservation of ecosystem services. Among the many ecosystem services provided, the biodiversity of constructed wetlands has received less attention. The EcoSistema Filtro (ESF) of the Molentargius-Saline Regional Natural Park is a constructed wetland situated in Sardinia (Italy), built to filter treated wastewater, increase habitat diversity and enhance local biodiversity. A floristic survey has been carried out yearly one year after the construction of the artificial ecosystem in 2004, observing the modification of the vascular flora composition in time. The flora of the ESF accounted for 54\% of the whole Regional Park's flora; alien species amount to $12 \%$, taxa of conservation concern are $6 \%$. Comparing the data in the years, except for the biennium 2006/2007, we observed a continuous increase of species richness, together with an increase of endemics, species of conservation concern and alien species too. Once the endemics appeared, they remained part of the flora, showing a good persistence in the artificial wetland.

Included in a natural park, but trapped in a sprawling and fast growing urban context, this artificial ecosystem provides multiple uses, by preserving and enhancing biodiversity. This is particularly relevant considering that biodiversity can act as drivers of sustainable development in areas where most of the world's population lives and comes into direct contact with nature.
\end{abstract}

\title{
Highlights
}

- Plant diversity of constructed wetlands has received little attention.

- The flora of the ESF accounted for $54 \%$ of the whole Regional Park's flora.

- Once the endemics appeared they all remained, showing persistence in the ESF habitat.

- Non-native species are significant, amounting to the $12 \%$ of the flora.

- Artificial ecosystems assure multiple uses, including enhancing local biodiversity.

Key words: Molentargius-Saline Regional Natural Park; multi-temporal; Sardinia; vascular plants.

\section{Introduction}


Constructed wetlands (CW) are artificial wetlands designed to mimic natural wetland ecosystems, in order to filter wastewater and remove pollutants before discharge into natural water bodies (Scholz et al. 2007, Vymazal 2010). Several studies have demonstrated that constructed wetlands are effective for the management of municipal and agricultural wastewater and for the removal of nutrients, trace elements and microorganisms therein contained (see Scholz et al. 2007); for those reasons, $\mathrm{CW}$ are widely used as low-cost alternatives to traditional wastewater treatment worldwide (Zhang et al. 2014, Zhi \& Ji 2012). In many countries within the Mediterranean basin, constructed wetlands have successfully reduced pollution (Masi \& Martinuzzi 2007, Masi et al.2000,Scholz et al. 2007, Vymazal 2010) and contributed to conservation of ecosystem services (Barbera et al. 2014, Masi \& Martinuzzi 2007, Rousseau et al.2008, Zhang et al. 2014). Among the many ecosystem services provided, the biodiversity of constructed wetlands received less attention in assessment of CW success (Hsu et al. 2011, Kearney et al. 2013). In particular, the vascular flora and rates of plant species colonization have rarely been investigated (White et al. 2012). The EcoSistema Filtro (ESF, Filtering EcoSystem) is a constructed wetland inserted in a Regional Natural Park, surrounded by a densely populated urban system in the Gulf of Cagliari, southern Sardinia (Italy),completed in October 2004. Since then, there has been a constant monitoring of the vascular flora of this area that in a few years has become a reservoir of unique genetic diversity, providing ecosystem services and indirectly supporting the sustainable development of the local urban area (see Capotorti et al. 2013, Crane \& Kinzig 2005).

The objective of this paper is to document changes and rates of change in the vascular plant flora of the artificial ecosystem since its creation, in terms of plant composition observed over the years.

\section{Materials and Methods}

\subsection{Study area}

The ESF is situated in Italy, in southern Sardinia in the Gulf of Cagliari, within the MolentargiusSaline Regional Natural Park (fig. 1; UTM WSG84 32S 513966 E, 4343085 N). The area takes up a 
wetland of international importance marked by the presence of outstanding biodiversity linked to its

different freshwater and salt water environments (e.g. Blasi et al 2011; Marignani et al. 2014). The freshwater basins are Bellarosa Minore, Perdalonga and the ESF, while the salt water basins are Bellarosa Maggiore, Perda Bianca and the Salt Pans.

The park was established in 1999, covering a surface area of 1466.80 ha: it is included in the European Natura 2000 network (Site of Community Importance ITB040022 - Stagno di Molentargius e territori limitrofi; Special Protection Area ITB044002 - Saline di Molentargius) and in the Ramsar Convention on Wetlands (Saline di Molentargius, Ramsar site n.133). The bioclimate of the area is comprised among the Upper Thermomediterranean, Lower Dry, Euoceanic Strong and the Upper Thermomediterranean, Lower Dry, Euoceanic Weak (Canu et al., 2015).

From ancient times, first written information dating back to the 1st century B.C., this area has been used to collect salt for human use; only at the end of 1990's the use of the ponds ceased, due to high management costs and sanitary problems. The ESF was built to take care of the problem of wastewater and the connected sanitary problems.

\subsection{Biofiltering technology: origins and characteristics of the EcoSistema Filtro}

The ESF is a Free Water Surface System (FWS) covering about 37 hectares (fig. 1). The ESF receives wastewater from sewage treatment of the Is Arenas depurator, following a finishing treatment through a phyto-purification, and finally feeds the Park's freshwater basins of Bellarosa Minore and Perdalonga with purified-quality water, in lieu of the sewage effluent which at one time fed these basins through the streams Mortu, Selargius and Is Cungiaus. The ESF performs a twofold action: it provides secondary treatment of the water coming from the Cagliari treatment plant, and it supplies and controls the water and biochemical balance of Bellarosa Minore and Perdalonga. The constructed wetland is the heart of an extensive, complex system of works carried out on the Park in the period 1990-March 2004, in the framework of the "Programme for safeguarding the coastal areas and wetlands of international importance of the Cagliari metropolitan 
area" (pursuant to Article 17(20), of Law No 67 of 11/03/1988 and Article 73(3) of Legislative Decree $\mathrm{N}^{\mathrm{o}} 112$ of 31/03/1998), launched by the Italian Ministry for the Environment. In 1990, at the time of the detailed design, creation of a constructed wetland represented a highly innovative solution to water treatment concerns, especially in view of the quantity of water to be treated (Qav of 300 1/s and Qmax of 400 1/s) and the size of the filtering area. The rationale for sizing the system at 37 hectares overall was based on an average pond depth of $55 \mathrm{~cm}$, to treat a flow of $300 \mathrm{l} / \mathrm{s}$, estimating a residence time of about 6 days. The net water surface area needed to meet this requirement was estimated at 27 hectares. The remaining area comprises the bank and dry land areas, which serve as nesting habitats for the bird population, and as vegetated areas for the environmental and landscape development of the system. The ESF has an average width of about $200 \mathrm{~m}$ and a length of $1900 \mathrm{~m}$. Its long and narrow structure develops along two parallel lines (fig. 1). This solution, obtained by creating a longitudinal bank, was chosen to obtain an internal subdivision of the biofilter system, so as to circumscribe maintenance and cutting down of the reed beds to limited areas, which can be drained without compromising the system's filtering action.The two main lines of the ESF are sectioned by several transverse baffles communicating by means of sluice gates which are normally left open. This makes it possible to cut off some of the tanks (a total of 12 tanks, mean water depth $55 \mathrm{~cm}$ ) from water circulation, achieving maximum operational flexibility, allowing variation of water residence time and hence optimising the purification action of the ESF. At the end of the two lines there is a final equalization basin that tapers until it connects with the outflow canal which conveys the water back close to the inflow point (fig. 1). This type of water treatment system uses emergent macrophytes, which are very effective water purification agents. Their action is based on the cooperative growth of macrophytes and associated bacteria, which are responsible for a good part of the degradation of organic matter (e.g. Zhi \& Ji 2012). The plants remove part of the undesirable substances by direct assimilation and provide a favourable habitat for the bacteria that transform the pollutants and reduce their concentration. 
The ESF has been constructed on the salty basin of Bellarosa Maggiore, a pond used in the recent past as salt evaporation pond: during the construction, all the existing vegetation were removed (see ESF 2004, fig.2).

To check for the degree of salinity of soils, in September 2005 soils samples were taken at different depth, showed an increasing level of salinity (0-15 cm: 2,8\%; 15-30 cm: 7,7\%; 30-50 cm: 12,7\%). 1/s) and it increased in May 2008, letting flow an amount of water lower than the potential capacity of the treatment plant $(\mathrm{Qav}=150 \mathrm{l} / \mathrm{s})$, with an estimated residence time of water was of $9 / 10$ days. In September 2008 the ESF started to treat the planned quantity of water (Qav of 230-350 1/s), with an estimated residence time of water of 5/6 days. The chemical composition of ESF water varied during the seasons and the years (table 1). For example, the synthetic indicator ratio of the inorganic fraction of the nitrogen and phosphorus soluble fraction $(\mathrm{N} / \mathrm{P})$ shows a change from a condition of phosphorus limitation to nitrogen limitation.

ESF was planted in May/November 2004 with fascines of $2 \mathrm{~m}$ height of Phragmites australis (Cav.) Trin. ex Steud., which is known to play an active role in the polishing water process (GuittonnyPhilippe et al.2015): the density of plantation varied from 12 fascines per sqm along the banks and 1/48 sqm in the water tanks. To thicken the area where Phragmites australis did not grow properly, in 2005/2006 some localized interventions have been made. From 2005 to 2007, the ordinary management of ESF included the mechanical removal of plant biomass from April to November, especially in the overflow channel; after few years of testing the results of this kind of management, the practise ceased. After the construction of ESF, birds recolonized the area, showing an increasing trend of colonization and nesting (approximately 9\% per year from 2005 to 2011) in line with the general trend of the park that hosts, among the others, one important colony of flamingos (Phoenicopterus ruber roseus, see Balkiz et al 2010). 
In october 2008, the area experienced a flash flood (rain estimated $90 \mathrm{~mm} / 3$ hours) that provoked

\subsection{Data gathering and floristic identification}

Floristic investigation was carried out during the period 2005-2013 using a mixed protocol: three squared plots (16 sqm) were surveyed every year in April/July and in September/December ( 8 samples per year), to cover the main flowering periods. In addition, to complete the list of species, periodic walking survey were conducted, at least one per months, collecting data on species. The samples collected were identified according to Tutin et al. $(1964-1980,1993)$ and Pignatti (1982). The nomenclature adopted is Conti et al. (2005) and further updates (Conti et al. 2007; Greuter \& Raus 2007, Iamonico 2009a, 2012, Peruzzi 2010a, Costalonga 2012); other floras were also consulted such as "Flora Europaea" (Tutin et al. 1964-1980, 1993) and Med-Checklist (Greuter et al. 1984-1989, Greuter \& Raab-Straube 2008). For specific groups, we consulted the monographs and the most recent taxonomic works (De Martis et al. 1984, Iberite 1996, 2004, Cuccuini 2002, Banfi et al. 2005, Valdés \& Scholz 2006, Greuter et al. 2006, Urbani et al. 2007, Manns \& Anderberg 2009, Iamonico 2008, 2009b, 2013, Köcke et al. 2010, Fuentes-Bazan et al. 2012). For the endemic species, we considered the works of Arrigoni et al. (1977-1991), the monographs on the endemic flora of Iglesiente and Sulcis (Bacchetta \& Pontecorvo 2005, Bacchetta et al. 2007) and a recent publication on endemic flora (Peruzzi et al. 2014). For Author's abbreviations we followed Brummitt \& Powell (1992), as recommended by the International Code of Botanical Nomenclature (Greuter et al. 2000).

In the floristic list (Annex I) the systematic arrangement follows the guidelines of Peruzzi (2010b), which is based on the studies of Chase \& Reveal (2009) and Haston et al. (2007, 2009), in accordance with the classification proposed by the Angiosperm Phylogeny Group (Stevens 2008, APG III 2009). 


\section{Results}

\subsection{The flora of ESF}

The flora of ESF comprised 275 taxonomic units, including 201 specific entities, 72 subspecific taxa and 2 varieties, distributed in 25 orders, 51 families and 161 genera. The most represented families as to number of genera and of taxonomic units are Asteraceae (49), Poaceae (39), Fabaceae (33), Amaranthaceae (18) and Caryophyllaceae (11). In regards to the biological forms, spectrum analysis shows the marked Mediterranean nature of the area, with a prevalence of Therophytes (56\%) indicating considerable summer aridity, by a sizeable percentage of Hemicryptophytes $(18,8 \%)$ and Phanerophytes $(9,1 \%)$; the presence of Geophytes $(8,4 \%)$ indicates a certain degradation of the territory whereas the Chamaephytes $(5,8 \%)$ are linked to the area's wind exposure. On the other hand, Hydrophytes are scantly represented (1,8\%) in spite of the fact that it is a wetland environment.

Examination of the geographical elements confirms the Mediterranean nature of the flora: the

Mediterranean component, including endemic plants, reaches $63 \%$. A sizable Eurasian component is present $(6,5 \%)$ whereas the entities of wider distribution reach $27,6 \%$.

Among the taxonomic units found, six are endemic (Peruzzi et al. 2014): Euphorbia pithyusa L. subsp. cupanii (Guss. ex Bertol.) Radcl.-Sm.; Limonium dubium (Guss.) Litard.; Limonium retirameum Greuter \& Burdet subsp. retirameum; Scorzoneroides muelleri (Sch. Bip.) Greuter \& 
Talavera subsp. muelleri; Stachys glutinosa L.; Tolpis virgata (Desf.) Bertol. subsp. grandiflora (Ten.) Arcang.

Ten taxa (about 4\%) are listed as species of conservation concern: all elements are listed in the Regional Red List (Conti et al. 1997) and two, Cynomorium coccineum L. subsp. coccineum and Limonium avei (De Not.) Brullo, are also included in the National Red List (Conti et al. 1992). At regional level Limonium avei (De Not.) Brullo and Erben and Lupinus luteus L. are considered endangered (EN), Phleum arenarium L. subsp. caesium H. Scholz and Salicornia emerici DuvalJouve are listed as vulnerable (VU), Marrubium alyssum L., Ranunculus sceleratus L. and Salicornia patula Duval-Jouve are included in the low risk category (LC); moreover, Centaurium pulchellum (Sw.) Druce subsp. pulchellum and Zannichellia palustris L. subsp. palustris are data deficient (DD, sensu IUCN, 2001). A total of 32 species in the flora of ESF are alien. Among those, 25 are reported in the inventory of the non-native flora of Italy (Celesti-Grapow et al. 2009): 3 are archaeophytes and 17 neophytes, while the remaining 5 are included in the doubtful aliens, since there are no sufficient information to define their status. Considering invasiveness, fifteen species were classified as invasive and five as naturalized. In the checklist of the alien flora of Sardinia (Bacchetta et al. 2009, Podda et al. 2012a, 2012b) almost all alien taxa surveyed in ESF are reported (except Lycium barbarum L.): 13 belong to archaeophytes and 18 to neophytes. Most of the taxa are classified as invasive (14), six are naturalized species, a small number are defined as casual (4) and a group of 7 are cryptogenic entities, whose native or introduced status remain undefined. The biological spectrum of alien species show a prevalence of Therophytes $(T=46.9 \%)$ and Phanerophytes $(\mathrm{P}=28.1 \%)$, followed by Geophytes $(12.5 \%)$, Hemicryptophytes $(9.4 \%)$ and, finally, Chamaephytes (3.1\%). Compared to the spectrum of native flora, the alien flora is composed of fewer annual species and more shrub and tree species. The majority of species come from the Americas (34,4\%) and Eurasia (21,9\%), followed by species of African (9,4\%) Australian $(9,4 \%)$, and Tropical origin (3,1\%). A consistent presence is represented by archaeophytes species belonging to the Mediterranean area $(21,9 \%)$. 


\subsection{The changes observed in the ESF flora in the years (2005/2013)}

Comparing the data through the years, except for the years 2006/2007, probably caused by the mechanical removal of the biomass conducted to manage the ESF until 2007, we observed a continuous increase of species richness, together with an increase in species of conservation concern and non-native species (figure 3, table 2, Annex II). The number of taxa increased at an annual rate of about $14 \%$ (fig. 3).

In 2006, the first endemic species Limonium dubium (Guss.) Litard. appeared in the constructed wetland, followed in 2007 by Limonium retirameum Greuter \& Burdet retirameum, Euphorbia pithyusa L. subsp. cupanii (Guss. ex Bertol.) Radcl.-Sm. and Tolpis virgata (Desf.) Bertol. subsp. grandiflora (Ten.) Arcang.. In 2008/2009 T.virgata was not documented as present, maybe suffering from the 2008 flood event, but it was found again in 2010. After a few years the number of endemics stabilized around 6 taxa. Except in the case of Tolpis virgata (Desf.) Bertol. subsp. grandiflora (Ten.) Arcang., once the endemics appeared in the wetland they remained as part of the flora, showing high rates of persistence in the constructed wetland habitat.

Species of conservation concern showed a different behaviour: Salicornia patula Duval-Jouve and Limonium avei (De Not.) Brullo \& Erben arrived in the first year and stably remained, while others like Ranunculus sceleratus L. and Salicornia emerici Duval-Jouve appeared and disappeared to show up again in the last years (2010-2013). Zannichellia palustris L. subsp. palustris sporadically appeared only in 2005 and 2008: its presence is probably linked to the availability of running fresh water in the outflow canal that was maintained by the mechanical removal of biomass.

Non-native species increased their number in the monitored years, showing a relative decrease of presence in the second year (2007), followed by an annual increasing rate of $7 \%(2007 / 2013)$.

About $22 \%$ of these species appeared in the first year of monitoring and remained in the ESF until 2013 (Amaranthus albus L.; Erigeron bonariensis L.; Nicotiana glauca Graham; Dysphania ambrosioides (L.) Mosyakin \& Clemants; Symphyotrichum squamatum (Spreng.) G.L. Nesom; 
Glebionis coronaria (L.) Spach; Melilotus siculus (Turra) Steud.). A consistent group of species $(25 \%)$ were sporadically present only one (6 taxa) or three times ( 2 taxa) in 8 years.

\section{Discussion}

After the construction of the ESF and planting of the reed bed, plant colonization took place following a constant and gradual increment, with the highest expansion during the first and second year. This trend is confirmed by several examples (Hsu et al.2011, Shelef et al.2013, White et al. 2012) but it cannot be considered a general behaviour of constructed wetlands (Kearney et al. 2013). In the period 2005-2013, the flora of the ESF accounted for $53,7 \%$ of the whole Molentargius-Saline Regional Park's flora (512 taxonomic units distributed over 364 species, 146 subspecies, 2 varieties, belonging to 71 families and 285 genera. See De Martis 2008, De Martis \& Mulas 2008, De Martis \& Atzeni 2009, De Martis 2011). The rich floristic composition of this peculiar environment can be attributed to its location between a freshwater basin, Bellarosa Minore, and a saline one, Bellarosa Maggiore.

The value of the flora is represented by the presence of endemic species that took advantage of the new saline and nitrogen rich habitats developed after the construction of ESF: Euphorbia pithyusa L. subsp. cupanii (Guss. ex Bertol.) Radcl.-Sm., a Tyrrhenian endemism widespread especially in nitrogen-rich, disturbed environments and in arid uncultivated terrain (Valsecchi 1980); Limonium dubium (Guss.) Litard., a Tyrrhenian endemism growing in coastal and subcoastal salt marsh environments (Arrigoni \& Diana 1985); Limonium retirameum Greuter and Burdet subsp. retirameum, an endemism of south-eastern Sardinia, preferring coastal sandy and rocky terrain (Arrigoni \& Diana 1991, Arrigoni 2005). Scorzoneroides muelleri (Sch. Bip.) Greuter \& Talavara subsp. muelleri, endemic to the north Italian peninsula (Liguria not confirmed), Sicily and Sardinia (Peruzzi et al. 2014), preferably lives in wet and saline habitats. Tolpis virgata (Desf.) Bertol. subsp. grandiflora (Ten.) Arcang., belonging to a predominantly insular plant genus, is endemic to central-southern Italy and Sicily (Peruzzi et al. 2014) and according to Greuter \& Raus (2007) is the 
only subspecies present in Sardinia. Finally, Stachys glutinosa L., a Tyrrhenian endemism, living from sea level up to the highest mountains, indifferent to the geological substrate, it thrives in full sun and avoids shade (Camarda 1980). This latter endemic species has been found only recently in the ESF and hence is not mentioned in earlier works on the Park (De Martis 2008, De Martis \& Mulas 2008).A pattern of increasing floristic diversity over time was observed from these repeated floristic surveys of the ESF. Highlights of this pattern include observation of two elements of the flora recorded in the Red List of endangered plants recognised both at national and regional level (Conti et al. 1992, 1997, Pignatti et al. 2001, Scoppola \& Spampinato 2005). Those two species are considered vulnerable at national level: Cynomorium coccineum L. subsp. coccineum, a parasitic plant living on the roots of several plants in saline or brackish coastal environments of Sicily and Sardinia and Limonium avei (De Not.) Brullo and Erben, a rare species with scattered distribution, which lives in lagoons and salt marshes of the western Mediterranean (Brullo 1988, Conti et al. 1997, Scoppola \& Spampinato 2005).

The presence of non-native species in the flora of ESF is significant: this indicates that a considerable contribution to the colonization of this territory comes from surrounding areas where human activity and disturbance has led to an increase in the number of alien species (Bartomeus et al. 2012, De Martis 2008, De Martis \& Mulas 2008) and also, probably, by the action of migratory waterbirds (García-Álvarez et al. 2015).

Alien species in 2013 amounted to the $11,6 \%$ of the flora of this study. This percentage is below the national average (13.4\%, Celesti-Grapow et al. 2009) and higher than that indicated for Sardinia (9\%, Celesti-Grapow et al. 2010a, Camarda et al. 2010). Among the non-native plants we mentioned, Lycium barbarum L. was recently reported for Sardinia in the areas of Assemini, Sestu and in the Bellarosa Minore (Mulas et al. 2008). Furthermore, we observed the occurrence of Cortaderia selloana (Schult. \& Schult. f.) Asch. \& Graebn., a perennial grass introduced into Europe from South America, considered as invasive worldwide (e.g. Bacchetta et al. 2010). This species causes a strong visual impact by altering ecosystem naturalness, by competing with native 
species (Herrera \& Campos 2006) and by adapting easily both in natural and rural habitats

(Domènech 2005); it is therefore considered a landscape modifier, like Opuntia ficus-indica (L.) Miller (Brundu et al. 2003).

The changes in the flora of the ESF reported here document a general increase of species corresponding to an increase in species of conservation concern and alien species. The increasing presence of visiting and nesting birds in the ESF surely contributed to the development of a diversified flora, as described in García-Álvarez et al. (2015) and Green \& Elmberg (2014). The once exception occurred in the second year after the establishment of the constructed wetland, in this year we observed a local decrease in the general trend of increase (2006/2007): this is easily attributable to the mechanical removal of plants imposed by the ESF management procedures during the first three years: once the mechanical removal terminated, the number of species started again to increase. This is true for all the analysed categories except for the endemics: endemic taxa progressively recolonized the area in a few years, permanently finding a suitable habitat after the construction of the artificial ecosystem and showing a good fitness in human modified environments.

\section{Conclusion}

An updated flora of the EcoSistema Filtro is needed to inform future research on phytoremediation. Recent papers confirmed the positive performance of native macrophytes in constructed wetlands (Guittonny-Philippe et al. 2015, 2014). Floristic surveys conducted in the ESF from 2005-2013 have documented changes in the composition of vascular flora over time and describe the ecological differentiation and evolution of the plant communities.

The context within which the artificial ecosystem of ESF is located, its significant size and the role it plays within the natural Park, made it a unique constructed wetland of its kind in southern Europe. In fact, the ESF offers an ideal habitat for the stopover, wintering and nesting of bird species of considerable importance (e.g. Balkiz et al. 2010). The significance of the wetland for biodiversity 
conservation highlights the importance of identifying the correct balance between the need to protect and conserve wildlife and the operation and maintenance of a water treatment system located within a protected area.

Included in a natural park, but trapped in a sprawling and rapidly-growing urban context (Salvati \& Morelli 2014, Zoppi \& Lai 2014), the EcoSistema Filtro provides multiple uses e.g. filtering waters (Guittonny-Philippe et al. 2015, Shelef et al. 2013), carbon sequestration and stocking (Barbera et al.2014, Kayranli et al. 2010, Mander et al.2014) and preserving and enhancing local biodiversity (Hsu et al. 2011, Zhang et al. 2014, Zhi \& Ji 2012). The ESF is thus an example of a constructed habitat in an urban setting that has become a key reservoir of ocal and regional biological diversity and which currently provides primary ecosystem services (e. g. Capotorti et al. 2013). Sites such as the ESF are thus important because they can act as drivers of sustainable development in areas in which most of the world's population now lives and comes into direct contact with nature (Crane \& Kinzig 2005). 


\section{References}

Angiosperm Phylogeny Group III (2009) An update of the Angiosperm Phylogeny Group classification for the orders and families of flowering plants: APG III. Botanical Journal of the Linnean Society 161: 105-121. http://dx.doi.org/10.1111/j.1095-8339.2009.00996.x

Arrigoni, P.V. (2005) Note floristiche e tassonomiche sulla Flora della Sardegna. Parlatorea 7: 1721.

Arrigoni, P.V.\& Diana, S. (1985) Le piante endemiche della Sardegna. 171: Limonium dubium (Andr. ex Guss.) R. Lit. Bollettino della Società Sarda di Scienze Naturali 24: 289-294.

Arrigoni, P.V. \& Diana, S. (1991) Le piante endemiche della Sardegna. 200: Limonium retirameum Greuter et Burdet. Bollettino della Società Sarda di Scienze Naturali 28: 317-322.

Arrigoni, P.V., Camarda, I., Corrias, B., Diana, S., Nardi, E., Raffaelli, M. \& Valsecchi, F. (19771991) Le piante endemiche della Sardegna: 1-202. Bollettino della Società Sarda di Scienze Naturali 16-28.

Bacchetta, G. \& Pontecorvo, C. (2005) Contribution to the knowledge of the endemic vascular flora of Iglesiente (SW Sardinia - Italy). Candollea 60: 481-501.

Bacchetta, G., Mandis, G. \& Pontecorvo C. (2007) Contribution to the knowledge of the endemic vascular flora of Sulcis (SW Sardinia - Italy). Bocconea, 21: 155-166.

Bacchetta, G., Mayoral, O. \& Podda, L. (2009) Catálogo de la flora exótica de la isla de Cerdeña (Italia). Flora Montiberica 41: 35-61.

Bacchetta, G., Dettori, C.A., Mascia, F., Meloni, F.\& Podda, L. (2010) Assessing the potential invasiveness of Cortaderia selloana in Sardinian wetlands through seed germination study. Plant Biosystems 144(3): 518-527. 
Balkiz, Ö., Béchet, A., Rouan, L., Choquet, R., Germain, C., Amat, J.A., Rendòn-Martos, M., Baccetti, N., Nissardi, S., Özesmi, U. \& Pradel, R.(2010) Experience-dependent natal philopatry of breeding greater flamingos. Journal of Animal Ecology 79: 1045-1056. doi:10.1111/j.13652656.2010.01721.x

Banfi, E., Galasso, G. \& Soldano, A. (2005) Notes on systematics and taxonomy for the Italian vascular flora. Atti Società italiana Scienze naturali. Museo civico Storia Naturale Milano, 146(2): 219-244.

Barbera, A.C., Borin, M., Cirelli, G.L., Toscano, A. \& Maucieri, C. (2014) Comparison of carbon balance in Mediterranean pilot constructed wetlands vegetated with different $\mathrm{C}_{4}$ plant species. Environmental Science and Pollution Research doi:10.1007/s11356-014-2870-3

Bartomeus, I., Sol, D., Pino, J., Vicente, P. \& Font, X. (2012) Deconstructing the native-exotic richness relationship in plants: Native-exotic richness relationship. Global Ecology and Biogeography 21: 524-533. doi:10.1111/j.1466-8238.2011.00708.x

Blasi C., Marignani M., Copiz R., Fipaldini M., Bonacquisti S., Del Vico E., Rosati L. \& Zavattero L. (2011). Important Plant Areas in Italy: from data to mapping. Biological Conservation $144: 220$ 226.

Brullo, S. (1988) Miscellaneous notes on the genus Limonium (Plumbaginaceae). Willdenowia 17: $11-18$

Brummitt, R.K. \& Powell, C.E., (eds) (1992) Authors of plant names. Royal Botanic Gardens, Kew.

Brundu, G., Camarda, I. \& Satta, V. (2003) A methodological approach for mapping alien plants in Sardinia (Italy). In: Child, L.E., Brock, J.H., Brundu, G., Prach, K., Pyŝek, P., Wade, P.M., Williamson, M., (ed). Plant Invasions: Ecological Threats and Management Solutions. Backhuys Publisher, Leiden, pp. 41-62. 
Brundu, G., Camarda, I., Hulme, P.E., Vilà, M., Troumbis, A., Traveset, A. \& Moragues, E. (2004)

Comparative analysis of the abundance and distribution of alien plants on Mediterranean islands. In:

Arianotsou \& Papanastasis (eds.). Proceedings 10th MEDECOS Conference, April 25-May1, 2004, Rhodes, Greece, pp. 1-9.

Camarda, I. (1980) Le piante endemiche della Sardegna. 70: Stachys glutinosa L. Bollettino della Società Sarda di Scienze Naturali 19: 261-267.

Camarda, I. (1998) Considerazioni su alcune specie di antica e recente introduzione in Sardegna e loro dinamica di diffusione. Biocosme Mésogéen, 15(1): 89-108.

Camarda, I., Carta, L., Manca, M. \& Brundu, G. (2010) Sardegna. In: Celesti- Grapow, L., Pretto, F., Carli, E. \& Blasi, C. (eds.) Flora vascolare alloctona e invasiva delle regioni d'Italia. Casa Editrice Univ. La Sapienza, Roma, pp. 149-154.

Canu, S., Rosati, L., Fiori, M., Motroni, A., Filigheddu, R. \& Farris, E. (2015). Bioclimates of Sardinia (Italy). Journal of Maps, 11 (5): 711-718, doi: 10.1080/17445647.2014.988187

Capotorti, G., Del Vico, E., Lattanzi, E., Tilia, A. \& Celesti-Grapow, L. (2013) Exploring biodiversity in a metropolitan area in the Mediterranean region: The urban and suburban flora of Rome (Italy). Plant Biosystems 147: 174-185. doi:10.1080/11263504.2013.771715

Celesti-Grapow, L., Alessandrini, A., Arrigoni, P.V., Banfi, E., Bernardo, L., Bovio, M., Brundu, G., Cagiotti, M.R., Camarda, I., Carli, E., Conti, F., Fascetti, S., Galasso, G., Gubellini, L., La Valva, V., Lucchese, F., Marchiori, S., Mazzola, P., Peccenini, S., Poldini, L., Pretto, F., Prosser, F., Siniscalco, C., Villani, M.C., Viegi, L., Wilhalm T. \& Blasi C. (2009) Inventory of non-native flora of Italy. Plant Biosystems 143(2): 386-430.

Celesti-Grapow, L., Alessandrini, A., Arrigoni, P.V., Assini, S., Banfi, E., Barni, E., Bovio, M.,

Brundu, G., Cagiotti, M.R., Camarda, I., Carli, E., Conti, F., Del Guacchio, E., Domina, G., Fascetti, 
S., Galasso, G., Gubellini, L., Lucchese, F., Medagli, P., Passalacqua, N.G., Peccenini, S., Poldini, L., Pretto, F., Prosser, F., Vidali, M., Viegi, L., Villani, M.C., Wilhalm T. \& Blasi C. (2010a) Nonnative flora of Italy: Species distribution and threats. Plant Biosystems, 144(1): 12-28.

Celesti-Grapow, L., Pretto, F., Carli, E. \& Blasi C. (eds.) (2010b) Flora vascolare alloctona e invasiva delle regioni d'Italia. Casa Editrice Univ. La Sapienza, Roma, 208 pp.

Chase, M.W. \& Reveal, J.L. (2009) A phylogenetic classification of the land plants to accompany. APG III. Botanical Journal of the Linnean Society, 161(2): 122-127.

Conti, F., Manzi, A. \& Pedrotti, F. (1992) Libro rosso delle piante d'Italia. Ministero dell'ambiente, WWF Italia, Società Botanica Italiana, Roma, 637 pp.

Conti, F., Abbate, G., Alessandrini, A. \& Blasi, C. (2005) An Annotated Checklist of the Italian Vascular Flora. Palombi Editori, Roma, 420 pp.

Conti, F., Manzi, A. \& Pedrotti, F. (1997) Liste rosse regionali delle piante d'Italia. WWF Italia, Società Botanica Italiana,. Camerino, 139 pp.

Conti, F., Alessandrini, A., Bacchetta, G., Banfi, E., Barberis, G., Bartolucci, F., Bernardo, L.,

Bonacquisti, S., Bouvet, D., Bovio, M., Brusa, G., Del Guacchio, E., Foggi, B., Frattini, S., Galasso, G., Gallo, L., Gangale, C., Gottschlich, G., Grünanger, P., Gubellini, L., Iiriti, G., Lucarini, D., Marchetti, D., Moraldo, B., Peruzzi, L., Poldini, L., Prosser, F., Raffaelli, M., Santangelo, A., Scassellati, E., Scortegagna, S., Selvi, F., Soldano, A., Tinti, D., Ubaldi, D., Uzunov, D. \& Vidali, M. (2007) Integrazioni alla Checklist della flora vascolare italiana. Natura Vicentina 10 (2006): 574.

Crane, P., Kinzig, A. (2005). Nature in the Metropolis. Science 308: 1225-1225. doi:10.1126/science. 1114165 
Costalonga, S. (2012) Notulae alla flora esotica d'Italia, 6: 141-142. Informatore Botanico Italiano 42(2): 400 .

Cuccuini, P. (2002) Il genere Parapholis C.E. Hubbard (Poaceae) in Italia. Note tassonomiche e palinologiche. Webbia 57(1): 7-64.

De Martis, G. (2008) Parco Naturale Regionale Molentargius-Saline. Flora: stato attuale e confronto con le situazioni preesistenti. $\mathrm{PhD}$ dissertation, University of Cagliari, $227 \mathrm{pp}$.

De Martis, G. (2011) The Regional Natural Park of Molentargius-Saline: Guide to the flora. Ed. Coedisar, Cagliari, 223 pp.

De Martis, G. \& Mulas, B. (2008) La flora del Parco Naturale Regionale Molentargius-Saline: stato attuale e confronto con le situazioni preesistenti. Rendiconti del Seminario della Facoltà di Scienze dell’Università di Cagliari 78(2): 1-123.

De Martis, B., Loi, M.C. \& Polo, M.B. (1984) Il genere “Tamarix” (Tamaricaceae) in Sardegna. Webbia 37(2): 211-235.

De Martis, G. \& Atzeni, A. (2009) Biodiversity in the Regional Park of Molentargius-Saline. In Abis, E. (ed.): Sustainable planning: landscape, environment, energy. The Cagliari Metropolitan Area case study. Atti Convegno Future MAC09. Gangemi Editore spa, Roma, pp. 97-101.

Domènech, R. (2005) Cortaderia selloana invasion in the Mediterranea region: Invasiveness and ecosystem invasibility. $\mathrm{PhD}$ dissertation, Universitat Autònoma de Barcelona, 161 pp.

Fuentes-Bazan, S., Uotila, P. \& Borsch, T. (2012) A novel phylogeny-based generic classification for Chenopodium sensu lato, and a tribal rearrangement of Chenopodioideae (Chenopodiaceae). Willdenowia 42: 5-24. 
García-Álvarez, A., van Leeuwen, C.H.A., Luque, C.J., Hussner, A., Vélez-Martín, A., Pérez-

by geese and ducks: an experimental study. Freshwater Biology 60:1316-1329.

Green A.J. \& Elmberg J. (2014) Ecosystem services provided by waterbirds. Biological Reviews: $89,105-122$.

Greuter, W., Burdet, H.M. \& Long, G. (1984-89) Med-Checklist 1-3-4. Conservatoire et Jardin Botaniques de la Ville de Géneve.

Greuter, W., Mc. Neill, J., Barrie, F.R., Burdet, H.M., Demoulin, V., Filgueiras, T.S., Nicolson, D.H., Silva, P.C., Skog, J.E., Trehane, P., Turland, N.J. \& Hawksworth, D.L., (eds.) (2000)

International Code of Botanical Nomenclature (St. Louis Code). Koeltz Scientific Books, Königstein.

Greuter, W., Gutermann, W. \& Talavera, S. (2006) A preliminary conspectus of Scorzoneroides (Compositae, Cichorieae) with validation of the required new names .Willdenowia 36: 689-692.

Greuter, W. \& Raus T. (2007) Med-Checklist Notulae, 25. Willdenowia 37(1): 205-213.

Greuter, W. \& Raabe-Straube, E. von (2008) Med-Checklist, 2. - Dicotiledones (Compositae). Palermo, Genève \& Berlin - OPTIMA

Guittonny-Philippe, A., Masotti, V., Höhener, P., Boudenne, J.-L., Viglione, J. \& Laffont-Schwob, I. (2014) Constructed wetlands to reduce metal pollution from industrial catchments in aquatic Mediterranean ecosystems: A review to overcome obstacles and suggest potential solutions. Environment International 64: 1-16. doi:10.1016/j.envint.2013.11.016

Guittonny-Philippe, A., Petit, M.-E., Masotti, V., Monnier, Y., Malleret, L., Coulomb, B., Combroux, I., Baumberger, T., Viglione, J. \& Laffont-Schwob, I. (2015) Selection of wild 
macrophytes for use in constructed wetlands for phytoremediation of contaminant mixtures. Journal

of Environmental Management 147: 108-123. doi:10.1016/j.jenvman.2014.09.009

Haston, E., Richardson, J.E., Stevens, P.E., Chase, M.W. \& Harris, D.J. (2007) A linear sequence of Angiosperm Phylogeny Group II families. Taxon 56(3): 7-12.

Haston, E., Richardson, J.E., Stevens, P.E., Chase, M.W. \& Harris, D.J. (2009) The Linear Angiosperm Phylogeny Group (LAPG) III: a linear sequence of the families in APG III. Botanical Journal of the Linnean Society 161: 128-131.

Herrera Gallastegui, M. \& Campos Prieto, J.A. (2006) El carrizo de la pampa (Cortaderia selloana) en Bizkaia. Guía práctica para su control. Laboratorio de Botánica Dpto Biologia Vegetal y Ecologia, Bilbao, 43 pp.

Hsu, C.B., Hsieh, H.L., Yang, L., Wu, S.H., Chang, J.S., Hsiao, S.C., Su, H.C., Yeh, C.H., Ho, Y.S. \& Lin, H.J. (2011) Biodiversity of constructed wetlands for wastewater treatment. Ecological Engineering 37: 1533-1545. doi:10.1016/j.ecoleng.2011.06.002

Kayranli, B., Scholz, M., Mustafa, A. \& Hedmark, Å. (2010) Carbon storage and fluxes within freshwater wetlands: A critical review. Wetlands 30: 111-124. doi:10.1007/s13157-009-0003-4 Kearney, M.A., Fickbohm, S. \& Zhu, W. (2013) Loss of Plant Biodiversity Over a Seven-Year Period in Two Constructed Wetlands in Central New York. Environmental Management 51: 10671076. doi:10.1007/s00267-013-0035-7

Köcke, A.V., von Mering, S., Mucina, L. \& Kadereit, J.W. (2010) Revision of the Mediterranean and Southern African Triglochin bulbosa complex (Juncaginaceae). Edinburgh Journal of Botany 67: 353-398.

Iamonico, D. (2008) Nuove segnalazioni di Chenopodium album L. subsp. album per l'Italia e considerazioni di carattere morfologico. Archivio Geobotanico 11(1-2)(2005): 87-90. 
Iamonico, D. (2009a) Notulae Nomenclaturali alla Checklist della Flora vascolare Italiana 8: 1621.

Informatore Botanico Italiano 41(2): 358.

Iamonico, D. (2009b) I generi Chenopodium e Dysphania in Italia (Amaranthaceae). Stato attuale delle conoscenze. In: Peccenini S., Domina G. (Eds.) Gruppi critici della Flora d'Italia.. Univ. Roma Sapienza, Dip. Biol. Amb., Roma, 30-31 Ottobre 2009, pp. 13-14.

Iamonico, D. (2012) Notulae Nomenclaturali alla Checklist della Flora vascolare Italiana, 14: 1956.

Informatore Botanico Italiano 44(2): 398-399.

Iamonico, D. (2013) Chenopodium sensu lato (Chenopodiaceae, Chenopodioideae) nella flora vascolare italiana: chiave analitica dei generi. Informatore Botanico Italiano 45(1): 83-88.

Iberite, M. (1996) Contribution to knowledge of the genus Salicornia L. (Chenopodiaceae) in Italy. Annali Di Botanica (Roma) 54: 145-154.

Iberite, M. (2004) Le salicornie: metodologie di indagine e problematiche tassonomiche. Informatore Botanico Italiano 36(2):508-511.

IUCN (2001) IUCN Red List Categories and Criteria: Version 3.1. IUCN Species Survival Commission. IUCN, Gland (Switzerland) and Cambridge (U.K.), 30 pp.

IUCN (2010) The IUCN red list of threatened species, version 2010.4. IUCN Red List Unit,

Cambridge U.K. Available from: http://www.iucnredlist.org/ (accessed: 1 December 2014).

Manns, U. \& Anderberg, A.A. (2009) New combinations and names in Lysimachia (Mirsinaceae) for species of Anagallis, Pelletiera and Trientalis. Willdenowia 39(1): 49-54.

Mander, T., Dotro, G., Ebie, Y., Towprayoon, S., Chiemchaisri, C., Nogueira, S.F., Jamsranjav, B., Kasak, K., Truu, J., Tournebize, J. \& Mitsch, W.J. (2014) Greenhouse gas emission in constructed wetlands for wastewater treatment: A review. Ecol. Eng. 66, 19-35. doi:10.1016/j.ecoleng.2013.12.006 
Marignani M., Bacchetta G, Bagella S, Caria MC, Delogu F, Farris E, Fenu G, Filigheddu R \& Blasi

C (2014) Is time on our side? Strengthening the link between field efforts and conservation needs.

Biodiversity and conservation $23(2): 421-431$

Masi, F., Bendoricchio, G., Conte, G., Garuti, G., Innocenti, A., Franco, D., Pietrelli, L., Pineschi, G., Pucci, B. \& Romagnolli, F. (2000) Constructed wetlands for wastewater treatment in Italy: State-ofthe-art and obtained results, in: Proc. of the 7th IWA International Conference on Wetland Systems for Water Pollution Control, Orlando. pp. 979-985.

Masi, F. \& Martinuzzi, N. (2007) Constructed wetlands for the Mediterranean countries: hybrid systems for water reuse and sustainable sanitation. Desalination 215, 44-55.

doi:10.1016/j.desal.2006.11.014

Mulas, B., Orrù, G. \& De Martis, G. (2008) Notulae alla checklist della Flora vascolare italiana 6: 1496. Informatore Botanico Italiano 40(2): 256.

Peruzzi, L. (2010a) Notulae alla checklist della Flora vascolare italiana: 9: 1675-1677. Informatore Botanico Italiano 42(1): 383-384.

Peruzzi, L. (2010b) Checklist dei generi e delle famiglie della flora vascolare italiana. Informatore Botanico Italiano 42(1): 151-170.

Peruzzi, L., Conti, F. \& Bartolucci, F. (2014) An inventory of vascular plants endemic to Italy. Phytotaxa 168, 1-75.

Pignatti, S (1982) Flora d'Italia. 1-3. Edagricole Ed., Bologna.

Pignatti, S., Menegoni, P. \& Giacanelli, V. (eds.) (2001) Liste rosse e blu della flora italiana. A.N.P.A. Stato dll'ambiente 1. Alcagraf, Roma, 306 pp. + CD-Rom.

Podda, L., Lazzei, V., Mascia, F., Mayoral, O. \& Bacchetta, G. (2012a) The Checklist of the Sardinian Alien Flora: an Update. Notulae Botanicae Horti Agrobotanici Cluj-Napoca 40(2): 14-21. 
Podda, L., Lazzei, V., Mascia, F., Mayoral, O., Bacchetta G. (2012b) The Checklist of the

Sardinian Alien Flora: an Update. Annex I. Notulae Botanicae Horti Agrobotanici Cluj-Napoca 40(2).

Raunkiaer, C. (1934) The life form of plants and statistical plant geography. Oxford.

Rossi, G., Montagnani, C., Abeli, T., Gargano, D., Peruzzi, L., Fenu, G., Magrini, S., Gennai, M., Foggi, B., Wagensommer, R.P., et al. (2014) Are Red Lists really useful for plant conservation? The New Red List of the Italian Flora in the perspective of National Conservation policies. Plant Biosystems 148 (2), 187-190.

Rousseau, D.P.L., Lesage, E., Story, A., Vanrolleghem, P.A. \& De Pauw, N. (2008) Constructed wetlands for water reclamation. Desalination 218, 181-189. doi:10.1016/j.desal.2006.09.034

Salvati, L. \& Morelli, V. (2014) Unveiling Urban Sprawl in the Mediterranean Region: Towards a Latent Urban Transformation? International Journal of Urban and Regional Research 38, 1935 1953. doi:10.1111/1468-2427.12135

Scholz, M., Harrington, R., Carroll, P. \& Mustafa, A. (2007) The Integrated Constructed Wetlands (ICW) concept. Wetlands 27, 337-354. doi:10.1672/0277-5212(2007)27[337:TICWIC]2.0.CO;2

Shelef, O., Gross, A. \& Rachmilevitch, S. (2013) Role of Plants in a Constructed Wetland: Current and New Perspectives. Water 5, 405-419. doi:10.3390/w5020405

Scoppola, A., Spampinato, G., editors (2005) Atlante delle specie a rischio di estinzione. CD-ROM. In: Scoppola, A., Blasi, C., editors. Stato delle conoscenze della flora vascolare d'Italia. Palombi Editori, Roma.

Stevens, P.F. (2008) Angiosperm Phylogeny Website. Version 9, June 2008 [and more or less continuously updated since]. http:/www.mobot.org/MOBOT/research/AP. 
Tutin, T.G., Burges, N.A., Valentine, D.H., Walters, S.M. \& Webb, D.A. (1964-1980) Flora Europaea. 1-5. Cambridge, University Press.

Tutin, T.G., Burges, N.A., Chater, A.O., Edmondson, G.R., Heywood, W.H., Moore, D.M., Valentine, D.H., Walters, S.M. \& Webb, D.A. (1993) Flora Europaea. 1. Cambridge:, University Press.

Urbani, M., Becca, G. \& Ledda, M.G. (2007) Notes on sistematics and chorology of Asparagus L. in Sardinia (Italy). Bocconea, 21: 267-271.

Valdés, B. \& Scholz, H. (2006) The Euro+Med treatment of Gramineae - a generic synopsis and some new names. Willdenowia, 36(2): 657-669.

Valsecchi, F. (1980) Le piante endemiche della Sardegna. 83: Euphorbia cupanii Guss. ex Bertol. Bollettino della Società Sarda di Scienze Naturali 19:336-342.

Viegi, L. (1993) Contributo alla conoscenza della biologia delle infestanti delle colture della Sardegna nord-occidentale. I. Censimento delle specie esotiche della Sardegna. Bollettino della Società Sarda di Scienze Naturali 29:131-234.

Vymazal, J. (2010) Constructed Wetlands for Wastewater Treatment. Water 2, 530-549. doi:10.3390/w2030530

White, S.A., Taylor, M.D. \& Damrel, D.Z. (2012) Floral Colonization of a Free-Water Surface Constructed Wetland System in Grady County, Georgia. Castanea 77, 159-171. doi:10.2179/11-045

Zhang, D.Q., Jinadasa, K.B.S.N., Gersberg, R.M., Liu, Y., Ng, W.J. \& Tan, S.K. (2014) Application of constructed wetlands for wastewater treatment in developing countries - A review of recent developments (2000-2013). Journal of Environmental Management. 141, 116-131. doi:10.1016/j.jenvman.2014.03.015 
Zhi, W. \& Ji, G. (2012) Constructed wetlands, 1991-2011: A review of research development, 1

current trends, and future directions. Science of the Total Environment 441, 19-27.

doi:10.1016/j.scitotenv.2012.09.064

Zidorn, C. (2008). "Sesquiterpene lactones and their precursors as chemosystematic markers in the tribe Cichorieae of the Asteraceae". Phytochemistry (Amsterdam, The Netherlands) 69: 2270-2296.

Zoppi, C. \& Lai, S. (2014) Land-taking processes: An interpretive study concerning an Italian region. Land Use Policy 36, 369-380. doi:10.1016/j.landusepol.2013.09.011 
Table 1 Data on the main characteristics of water and soil of the EcoSistema Filtro. NAV indicates that data are not available.

2005

2007

2008

2009

20102011

Salinity of incoming/outgoing water

$(\mathbf{m i n} / \mathbf{m a x}$, PSU)

$1,59-43,4 \quad 0,73-2,38 \quad 0,75-4,39 \quad 0,68-3,39 \quad$ NAV $\quad$ NAV

\begin{tabular}{|c|c|c|c|c|c|c|c|}
\hline \multirow{3}{*}{$\begin{array}{l}\text { Biochemical Oxygen } \\
\text { Demand BOD5 (mean } \\
\text { value, mg/l) }\end{array}$} & \multirow{3}{*}{$\begin{array}{l}\text { Inflow } \\
\text { basin } \\
\text { outflow } \\
\text { canal }\end{array}$} & \multirow[b]{2}{*}{ NAV } & \multirow[b]{2}{*}{23} & \multirow[b]{2}{*}{9,5} & \multirow[b]{2}{*}{7,3} & \multirow[b]{2}{*}{ NAV } & \multirow[b]{2}{*}{ NAV } \\
\hline & & & & & & & \\
\hline & & NAV & 5 & 10,8 & 12,4 & NAV & NAV \\
\hline $\begin{array}{l}\mathrm{O}_{2} \text { concentration in the } \\
\text { ESF water (mean value, } \\
\mathrm{mg} / \mathrm{l} \text { ) }\end{array}$ & - & NAV & 3,18 & 4,08 & 4,32 & NAV & NAV \\
\hline \multirow[t]{2}{*}{$\begin{array}{l}\text { Water temperature } \\
\left(\min / \max ,{ }^{\circ} \mathbf{C}\right)\end{array}$} & $\begin{array}{c}\text { Inflow } \\
\text { basin }\end{array}$ & NAV & $15-26$ & $14-25$ & $13-26$ & NAV & NAV \\
\hline & $\begin{array}{c}\text { outflow } \\
\text { canal }\end{array}$ & NAV & $9-34$ & $6-34$ & $3-34$ & NAV & NAV \\
\hline N/P in the ESF water & - & NAV & 1,76 & 1,28 & 2,43 & 2,56 & 2,2 \\
\hline \multirow{2}{*}{$\begin{array}{l}\text { Soil sampled in the ESF } \\
(\mathrm{min} / \mathrm{max}, \mathrm{mg} / \mathrm{Kg})\end{array}$} & $\mathrm{N}$ & NAV & $400-2000$ & 476- 3440 & $433-2760$ & NAV & NAV \\
\hline & $\mathrm{P}$ & NAV & $300-700$ & $189-925$ & $193-1029$ & NAV & NAV \\
\hline
\end{tabular}


Table 2 Number of taxa, taxa of conservation concern, endemics and aliens species surveyed in the years in the constructed wetland ESF of Molentargius-Saline Regional Park. For a complete list, see annex II.

$\begin{array}{lllllllllll}\text { Number of } & \mathbf{2 0 0 5} & \mathbf{2 0 0 6} & \mathbf{2 0 0 7} & \mathbf{2 0 0 8} & \mathbf{2 0 0 9} & \mathbf{2 0 1 0} & \mathbf{2 0 1 1} & \mathbf{2 0 1 3} & \text { Total } \\ \text { Taxa } & 85 & 139 & 129 & 147 & 185 & 206 & 214 & 238 & 275 \\ \begin{array}{l}\text { Conservation } \\ \text { concern taxa }\end{array} & 4 & 5 & 3 & 4 & 3 & 6 & 6 & 7 & 10 \\ \text { Endemic taxa } & 0 & 1 & 4 & 4 & 4 & 5 & 5 & 6 & 6\end{array}$

$\begin{array}{llllllllll}\text { Alien taxa } & 11 & 18 & 14 & 19 & 22 & 24 & 26 & 27 & 32\end{array}$


Figure 1. The Filtering Ecosystem - ESF is surrounded by the salty basin Bellarosa maggiore and Bellarosa minore, a fresh water one. Wastewater enters from the inflow tank, reaches the last tank and leaves the ESF from the outflow canal. Arrows indicate the water direction, dotted lines the outflow canal (Source: "Molentargius" UTM WSG84 32S 513966 E, 4343085 N Google Earth March 14, 2013. November 20, 2014)

Figure 2. The evolution of the constructed wetland during the first five years after its original creation in 2004 (2004/2009). Color version of the pictures in the online version only.

Figure 3. Species richness increased over the nine years (2005-2013) in which floristic survey were conducted

Annex I - Complete floristic list

Annex II - Complete floristic list with presence of species in the years

\section{Acknowledgement}

We thank two anonymous referee for improving the first draft of the manuscript. One of authors (V. M.) gratefully acknowledges Sardinia Regional Government for the financial support (research grant cofinanced by POR Sardegna FSE 2007-2013 L.R.7/2007 "Promozione della ricerca scientifica e dell'innovazione tecnologica in Sardegna"). 


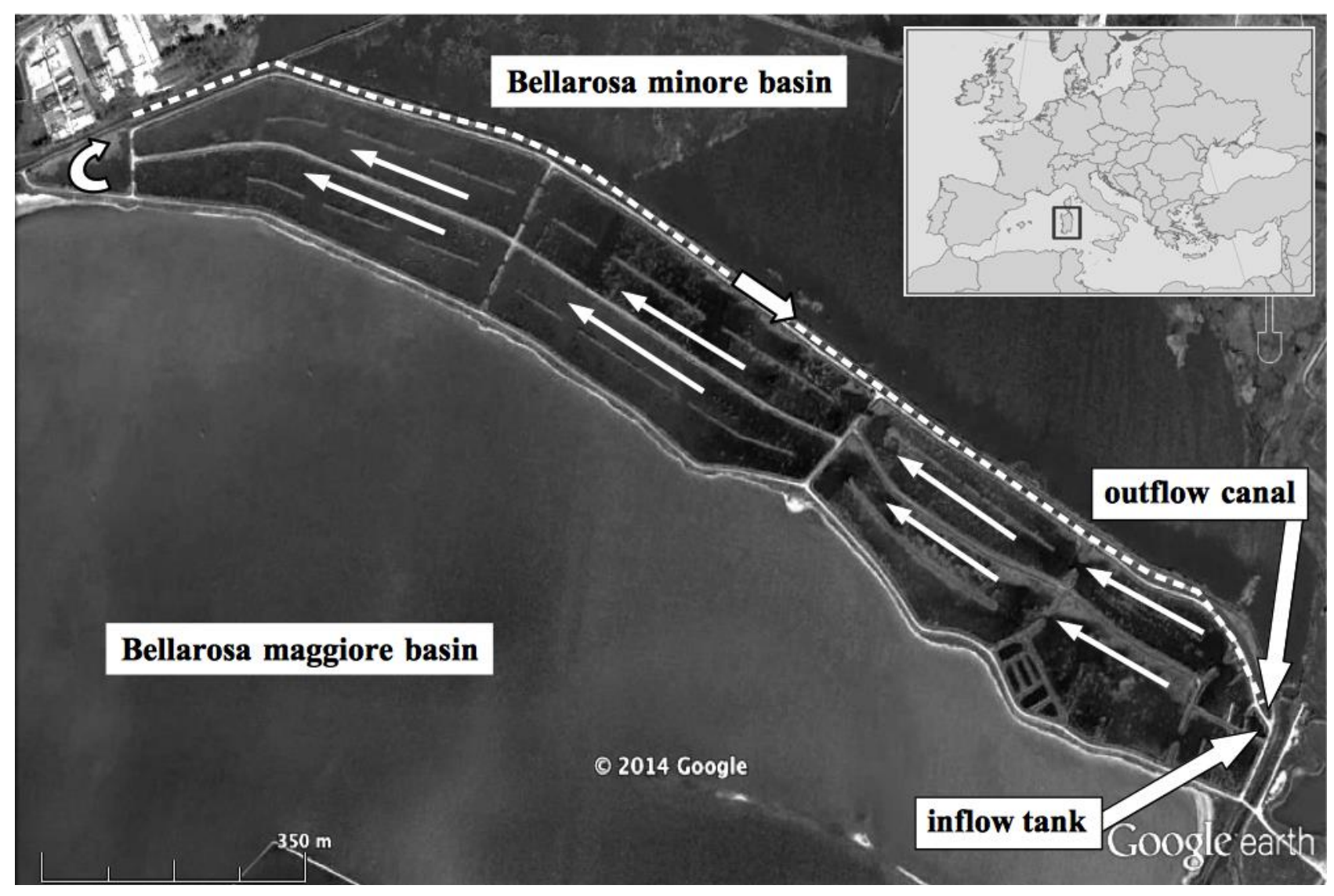

Figure 1 


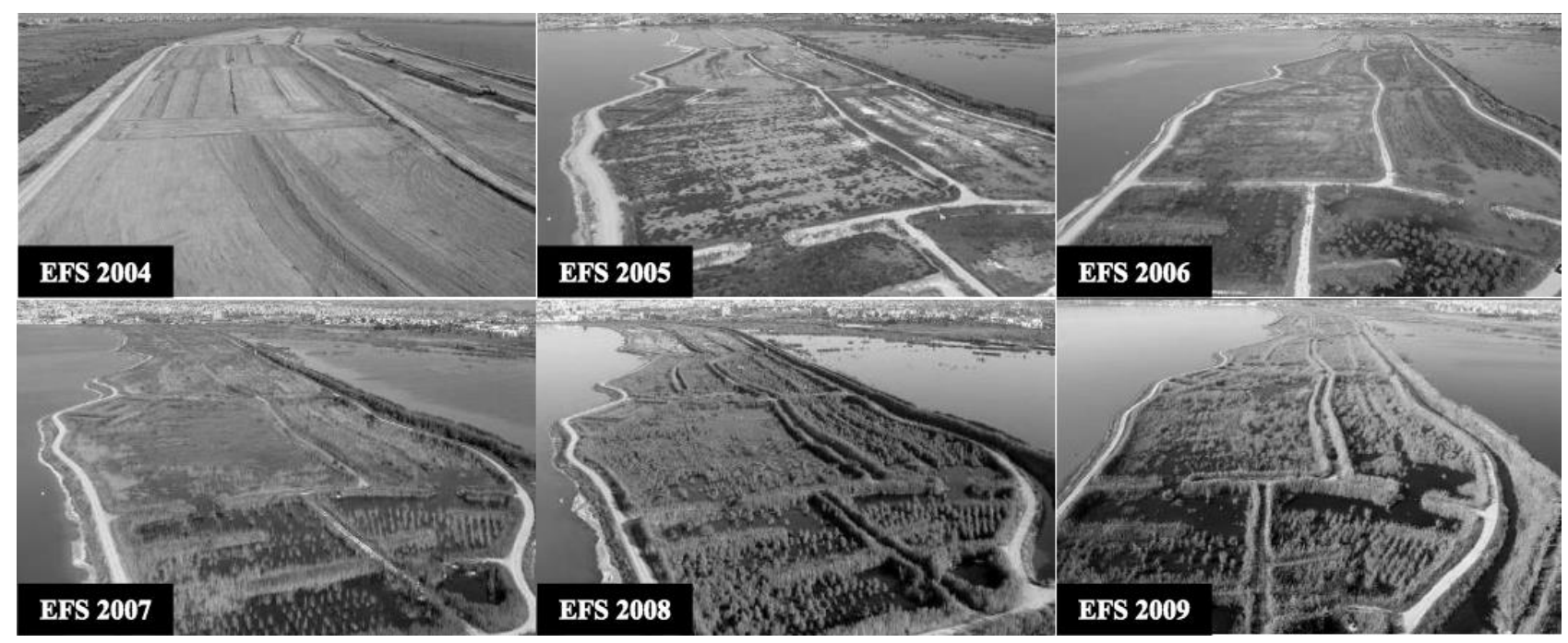

$1 \S 15$ Figure 2

19

20

21

22

23

24

25

26

27

28

29

30

31

32

33

34

35

36

37

38

39

40

41

42

43

44

45

46

47

48

49

50

51

52

53

54

55

56

57

58

59

60

61 


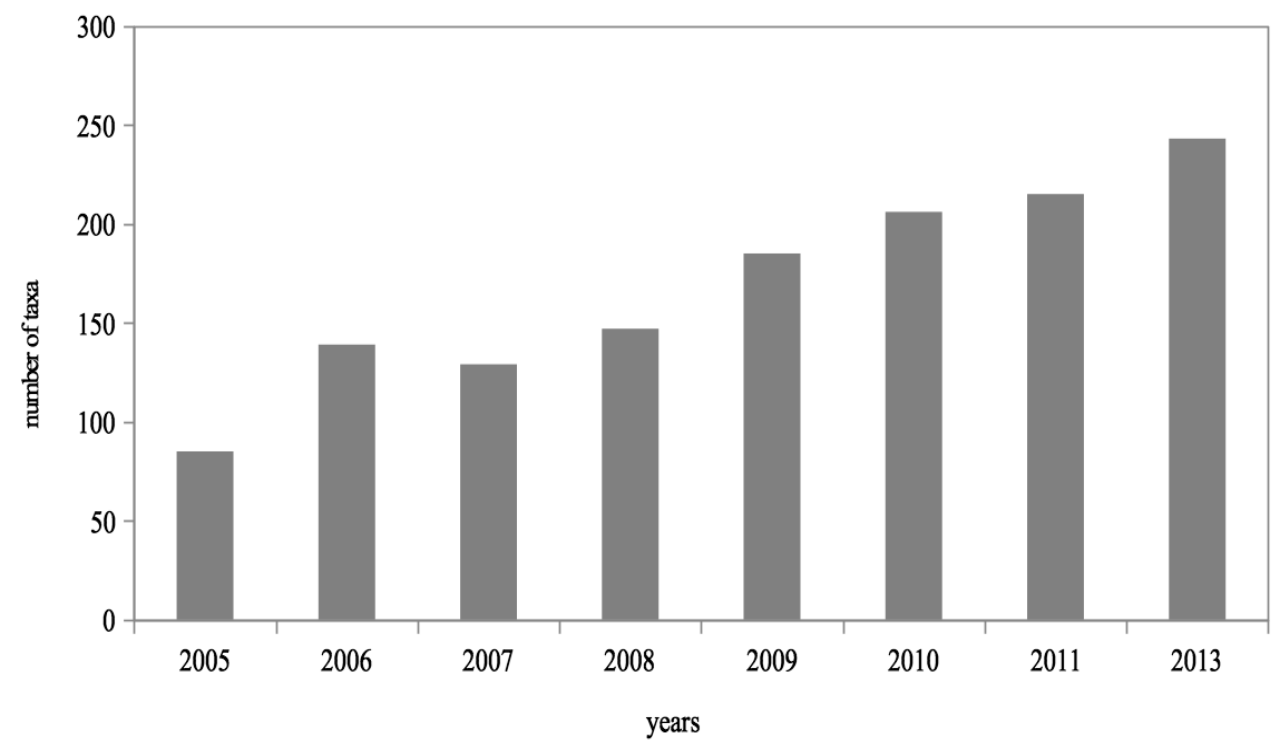


Can artificial ecosystems enhance local biodiversity? The case of a constructed wetland in a Mediterranean urban context -Environmental management - GABRIELE DE MARTIS ${ }^{1}$, BONARIA MULAS ${ }^{2}$, VERONICA MALAVASI ${ }^{3}$ \& MICHELA MARIGNANI ${ }^{2}$

\section{Annex I - Complete floristic list}

\section{Environmental Management}

Can artificial ecosystems enhance local biodiversity? The case of a constructed wetland in a Mediterranean urban context

\section{GABRIELE DE MARTIS ', BONARIA MULAS ${ }^{2}$, VERONICA MALAVASI ${ }^{3} \&$ MICHELA}

\section{MARIGNANI ${ }^{2}$}

1 Via Arcuentu 2/A, 09042 Monserrato, (CA), Italy; docdem73@gmail.com

2 Department of Life and Environmental Sciences - Botany and Botanical Garden Division,

University of Cagliari, Italy; mulas.bonaria@gmail.com ; marignani@unica.it

3 Interdepartmental Center of Environmental Science and Engineering (CINSA), University of

Cagliari, Via San Giorgio 12,09123 Cagliari, Italy; veronica.malavasi@unica.it

The taxa are listed in systematic order at the level of orders and families and, within those, genera, species and any infraspecific taxa follow the alphabetical order. For each entity we indicated the specific or sub-specific binomial followed, in order, by:

$\cong$ biological form and sub-form, verified in the field using the classification of Raunkiaer

(1934) and adopting the abbreviation of Pignatti (1982);

$\cong$ chorotype according to Pignatti (1982). In regards to the chorology of endemic species, we adopted the geographical groups proposed by Peruzzi et al. (2014).

$\cong$ non-native species, inserted in the list, are indicated with the terminology (Cas = casual; Nat = naturalized; Inv = invasive; $\mathrm{D}=$ doubtful) used by Celesti-Grapow et al. $(2009$,

2010a, 2010b); we furthermore consulted the works of Viegi (1993), Camarda (1998), Brundu et al. (2003, 2004), Camarda et al. (2010), Bacchetta et al. (2009) and Podda et al. (2010a, 2010b);

$\cong$ IUCN Status for the Sardinian flora according to Conti et al. (1997) and, in parentheses, for the Italian flora (Conti et al. 1992, 1997, Pignatti et al. 2001, Scoppola \& Spampinato

2005, Rossi et al. 2014). Using the latest version of the protocol IUCN (2001) and the guidelines for its application (IUCN 2010) the following categories can be found: EN $=$ endangered, $\mathrm{VU}=$ vulnerable, $\mathrm{LC}=$ lower risk, $\mathrm{DD}=$ insufficient data. 


\section{ARACEAE}

Arisarum vulgare $\mathrm{O}$. Targ. Tozz.

$\mathrm{G}$ rhiz - Steno-Medit.

\section{Lemna gibba L.}

I nat - Subcosmop.

Lemna minor L.

I nat - Subcosmop.

\section{JUNCAGINACEAE}

Triglochin barrelieri Loisel.

$\mathrm{G}$ bulb - Steno-Medit.

PotAMOGETONACEAE

Stuckenia pectinata (L.) Börner

I rad - Subcosmop.

Zannichellia palustris L. subsp. palustris

I rad - Cosmop. - DD

RUPPIACEAE

Ruppia maritima L.

I rad-Cosmop.

Asparagales

IRIDACEAE

Moraea sisyrinchium (L.) Ker Gawl.

$\mathrm{G}$ bulb - Steno-Medit.

XANTHORRHOEACEAE

Asphodelus fistulosus L.

H scap - Paleosubtrop.

\section{Arecales}

ARECACEAE

Washingtonia filifera (Lindl.) $\mathrm{H}$. Wendl.

P caesp - Nordamer. 


\section{COMMELINIDS}

\section{Poales}

TYPHACEAE

Typha angustifolia $\mathrm{L}$.

$\mathrm{G}$ rhiz - Circumbor.

JUNCACEAE

Juncus acutus L. subsp. acutus

H caesp - Euri-Medit.

Juncus hybridus Brot.

T caesp - Medit.-Atl.

Juncus maritimus Lam.

G rhiz - Subcosmop.

Juncus subulatus Forssk.

G rhiz - S-Medit.

CyPeraceae

Bolboschoenus maritimus (L.) Palla

G rhiz - Cosmop.

Cyperus rotundus L.

G rhiz - Subcosmop. - D

Schoenoplectus lacustris (L.) Palla subsp. lacustris

G rhiz - Subcosmop.

Schoenoplectus tabernaemontani (C.C. Gmel.) Palla

G rhiz - Eurosib.

Scirpoides holoschoenus (L.) Soják

G rhiz - Euri-Medit.

Anisantha madritensis (L.) Nevski

T scap - Euri-Medit.

Anisantha rubens (L.) Nevski

T scap - S-Medit.-Turan.

Anisantha sterilis(L.) Nevski 
T scap - Euri-Medit.-Turan.

Arundo donax L.

G rhiz - Subcosmop. - Inv

Avena barbata Pott ex Link

T scap - Euri-Medit.-Turan.

Bromus hordeaceus L. subsp. hordeaceus

T scap - Subcosmop.

Catapodium rigidum (L.) C.E. Hubb. subsp. rigidum

T scap - Euri-Medit.

Cortaderia selloana (Schult. \& Schult. f.) Asch. \& Graebn.

H caesp - Sudamer. - Inv

Cynodon dactylon (L.) Pers.

G rhiz - Termocosmop.

Cynosurus echinatus L.

T scap - Euri-Medit.

Hordeum marinum Huds. subsp. marinum

T scap - Euri-Medit.(Subatl.)

Hordeum murinum L. subsp. leporinum (Link) Arcang.

T scap - Euri-Medit.

Lagurus ovatus L. subsp. ovatus

T scap - Euri-Medit.

Lamarckia aurea (L.) Moench

T scap - Steno-Medit.-Turan.

Molineriella minuta (L.) Rouy

T scap - Steno-Medit.

Ochlopoa annua (L.) H. Scholz

T scap - Cosmop.

Parapholis filiformis (Roth) C.E. Hubb.

T scap - Medit.-Atl.

Parapholis incurva (L.) C. E. Hubb.

T scap - Medit.-Atl.

Paspalum distichum L. 
G rhiz - Subcosmop. - Inv

Phalaris minor Retz.

T scap - Paleosubtrop.

Phleum arenarium L. subsp. caesium H. Scholz

T scap - Medit.-Atl. - VU

Phragmites australis (Cav.) Steud. subsp. australis

G rhiz - Subcosmop.

Phragmites australis (Cav.) Steud. subsp. chrysanthus (Mabille) Kerguélen

G rhiz - Subcosmop.

Piptatherum miliaceum (L.) Coss. subsp. thomasii (Duby) Freitag H caesp - Steno-Medit.-Turan.

Polypogon maritimus Willd.

T scap - Steno-Medit.-Macarones.

Polypogon monspeliensis (L.) Desf.

T scap - Paleosubtrop.

Polypogon subspathaceus Req.

T scap - Steno-Medit.

Rostraria cristata (L.) Tzvelev subsp. cristata

T caesp - Subcosmop.

Rostraria hispida (Savi) Doğan

T scap - Steno-Medit.-Sudoccid.

Sphenopus divaricatus (Gouan) Rchb.

T scap - S-Medit.-Turan.

Trachynia distachya (L.) Link

T scap - Steno-Medit.-Turan.

Trisetaria panicea (Lam.) Paunero

T scap - Steno-Medit.-Macarones.

Vulpia geniculata (L.) Link.

T caesp - Steno-Medit.-Occid.

Vulpia myuros (L.) C.C. Gmel.

T caesp - Subcosmop. 


\section{EUDICOTS}

\section{Ranunculales}

\section{PAPAVERACEAE}

Fumaria capreolata L. subsp. capreolata

T scap - Euri-Medit.

Fumaria parviflora Lam.

T scap - Medit.-Turan.

\section{Papaver hybridum L.}

T scap - Medit.-Turan. - D

Papaver rhoeas L. subsp. rhoeas

T scap - E-Medit. - D

Papaver setigerum DC.

T scap - W-Medit. - D

RANUNCULACEAE

Delphinium gracile DC.

T scap - W-Medit.

Ranunculus sceleratus L.

\section{FABACEAE}

Acacia longifolia (Andrews) Willd.

$\mathrm{P}$ caesp - Australia - Nat

Acacia saligna (Labill.) H.L. Wendl.

P caesp - Australia - Inv

Anagyris foetida $\mathrm{L}$.

P caesp - S-Medit.

\section{Astragalus hamosus L.}

T scap - Medit.-Turan.

Bituminaria bituminosa (L.) C.H. Stirt.

H scap - Euri-Medit.

Calicotome villosa (Poir.) Link

$\mathrm{P}$ caesp - Steno-Medit. 


\section{Lathyrus clymenum L.}

T scap - Steno-Medit.

Lotus edulis L.

T scap - Steno-Medit.

Lotus ornithopodioides L.

T scap - Steno-Medit.

\section{Lupinus luteus L.}

T scap - W-Medit. - EN

Medicago doliata Carmign.

T scap - Steno-Medit.

Medicago praecox DC.

T scap - Steno-Medit.

Medicago rigidula (L.) All.

T scap - Euri-Medit.

Melilotus albus Medik.

T scap - Subcosmop.

Melilotus indicus (L.) All.

T scap - S-Medit.

Ononis natrix L. subsp. ramosissima (Desf.) Batt.

Ch suffr - Euri-Medit.

Ononis reclinata $\mathrm{L}$.

T scap - S-Medit.-Turan.

Ononis viscosa L. subsp. breviflora (DC.) Nyman T scap - W-Medit.

\section{Scorpiurus muricatus L.}

T scap - Steno-Medit.

Sulla capitata (Desf.) B.H. Choi \& H. Ohashi

T scap - W-Medit.

Sulla coronaria (L.) Medik.

H scap - W-Medit. - Nat 
Trifolium angustifolium L. subsp. angustifolium

T scap - Euri-Medit.

Trifolium arvense L. subsp. arvense

T scap - Paleotemp.

Trifolium campestre Schreb.

T scap - W-Paleotemp.

Trifolium lappaceum L.

T scap - Euri-Medit.

Trifolium pratense L. subsp. pratense H scap - Subcosmop.

Trifolium resupinatum $\mathrm{L}$.

T rept - Paleotemp.

Trifolium scabrum L. subsp. scabrum T rept - Euri-Medit.

\section{Rosales}

URTICACEAE

Parietaria judaica L.

H scap - Euri-Medit.-Macarones.

Urtica membranacea Poir. ex Savigny

T scap - S-Medit. T scap - S-Medit.

Urtica urens L.

T scap - Subcosmop.

\section{Cucurbitales}

Cucurbitaceae

Ecballium elaterium (L.) A. Rich.

$\mathrm{G}$ bulb - Euri-Medit.

\section{ROSID I}

\section{Oxalidales}




\section{OXALIDACEAE}

Oxalis pes-caprae L.

G bulb - Sudafr. - Inv

\section{Malpighiales}

\section{EUPHORBIACEAE}

Euphorbia helioscopia L. subsp. helioscopia

T scap - Cosmop.

\section{Euphorbia peplus L. T}

scap - Cosmop.

Euphorbia pithyusa L. subsp. cupanii (Guss. ex Bertol.) Radcl.-Sm.

G rhiz - Endem. SIC; SAR (Corsica)

\section{Euphorbia terracina L.}

P caesp - Paleotrop. - Inv

\section{SALICACEAE}

Salix cinerea L. subsp. oleifolia Macreight

P caesp - W-Medit.-Atl.

LINACEAE

Linum strictum L. subsp. strictum

T scap - Steno-Medit.

\section{ROSID II}

\section{Geraniales}

\section{GERANIACEAE}

Erodium ciconium (L.) L'Hér.

T scap - Euri-Medit.-Pontico

Erodium cicutarium (L.) L'Hér.

T scap - Euri-Medit.

Erodium moschatum (L.) L'Hér.

T scap - Euri-Medit.

Geranium molle L.

T scap - Subcosmop. 
Geranium rotundifolium $\mathrm{L}$.

T scap - Paleotemp.

\section{Myrtales}

\section{ONAGRACEAE}

\section{Epilobium hirsutum L.}

\section{Malvales}

MalvaceAe

Malva multiflora (Cav.) Soldano, Banfi \& Galasso

T scap - Steno-Medit.

Malva olbia (L.) Alef.

P caesp - Steno-Medit.

Malva sylvestris L. subsp. sylvestris

H scap - Subcosmop.

THYMELAEACEAE

Thymelaea hirsuta (L.) Endl.

$\mathrm{NP}$ - S-Medit.-W-Asiat.

Cistaceae

Cistus creticus L. subsp. eriocephalus (Viv.) Greuter \& Burdet NP - Steno-Medit.

Cistus monspeliensis L.

NP - Steno-Medit.-Macarones.

Cistus salviifolius L.

NP - Steno-Medit.

\section{Brassicales}

RESEDACEAE

Reseda alba L. subsp. alba

T scap - Steno-Medit. 


\section{BRASSICACEAE}

\section{Cardamine hirsuta L.}

T scap-Cosmop.

Eruca vesicaria (L.) Cav.

T scap - Medit.-Turan.

Hirschfeldia incana (L.) Lagr.-Foss. subsp. incana H scap - Medit.-Macarones.

Hornungia procumbens (L.) Hayek

T scap - Subcosmop.

Sinapis arvensis L. subsp. arvensis

T scap - Steno-Medit.

Sisymbrium irio L.

T scap - Paleotemp.

Sisymbrium orientale L. subsp. orientale

T scap - Euri-Medit. - Nat

\section{ASTERIDS}

\section{Caryophyllales}

\section{FRANKENIACEAE}

Frankenia laevis L. subsp. laevis

Ch suffr - Steno-Medit.-Centroasiat.-Sudafr.

\section{TAMARICACEAE}

Tamarix africana Poir. var. africana

P caesp - W-Medit.

Tamarix arborea Ehrenb. ex Bunge

T caesp - Medit.-Asiat.

Tamarix canariensis Willd.

$\mathrm{P}$ caesp - Medit.-Macarones.

Tamarix parviflora DC.

Ch suffr - Endem. SIC; SAR (Corsica) 
Limonium retirameum Greuter \& Burdet subsp. retirameum

Ch suffr - Endem. SAR

Limonium virgatum (Willd.) Fourr. Phleum

Ch suffr - Euri-Medit.

\section{POLYGOnACEAE}

Polygonum aviculare L. subsp. aviculare

T rept - Cosmop.

Rumex obtusifolius L. subsp. obtusifolius

H scap - Subcosmop.

Rumex pulcher L. subsp. pulcher

H scap - Euri-Medit.

\section{CARYOPHYLLACEAE}

Cerastium glomeratum Thuill.

T scap - Subcosmop.

Herniaria hirsuta L. subsp. hirsuta

T scap - Paleotemp.

Petrorhagia velutina (Guss.) P. W. Ball \& Heywood T scap - S-Medit.

Polycarpon tetraphyllum (L.) L. subsp. tetraphyllum

T scap - Euri-Medit.

Sagina apetala Ard. subsp. apetala

T scap - Euri-Medit.

\section{Silene gallica L.}

T scap - Subcosmop.

Spergularia bocconei (Scheele) Asch. \& Graebn.

T scap - Subcosmop.

Spergularia rubra (L.) J. \& C. Presl

Stellaria media (L.) Vill. subsp. media

T rept - Cosmop.

Stellaria pallida (Dumort.) Piré

T scap - Paleotemp. 


\section{AMARANTHACEAE}

Amaranthus albus L.

T scap - Nordamer. - Inv

Amaranthus blitoides S. Watson

T scap - Nordamer. - Inv

Arthrocnemum macrostachyum (Moric.) Moris

Ch succ - Medit.-Macarones.

Atriplex halimus L.

$\mathrm{P}$ caesp - Sudafr.

Atriplex patula L.

T scap - Circumbor.

Atriplex portulacoides L.

Ch frut - Circumbor.

Atriplex prostrata DC.

T scap - Circumbor.

Beta vulgaris L. subsp. maritima (L.) Arcang.

H scap - Euri-Medit.

Chenopodium album L. subsp. album

T scap - Subcosmop.

Dysphania ambrosioides (L.) Mosyakin \& Clemants

T scap - Cosmop. - Inv

Oxybasis urbica (L.) S.Fuentes, Uotila \& Borsch

T scap - Subcosmop.

Sarcocornia fruticosa (L.) A.J. Scott

Ch succ-Euri-Medit.-Sudafr.

Sarcocornia perennis (Mill.) A.J. Scott

Ch succ - Euri-Medit.

Suaeda maritima (L.) Dumort.

T scap - Cosmop.(alofila)

Suaeda vera J.F. Gmel. 
Can artificial ecosystems enhance local biodiversity? The case of a constructed wetland in a Mediterranean urban context -Environmental management - GABRIELE DE MARTIS ${ }^{1}$, BONARIA MULAS ${ }^{2}$, VERONICA MALAVASI ${ }^{3}$ \& MICHELA MARIGNANI ${ }^{2}$

Ch suffr - Cosmop.(alofila)

AizoACEAE

Mesembryanthemum nodiflorum $\mathrm{L}$.

T scap - S-Medit.-Sudafr. - Nat

\section{Ericales}

PRIMULACEAE

Lysimachia arvensis (L.) U. Manns \& Anderb. subsp. arvensis

T rept - Subcosmop.

\section{Gentianales}

RUBIACEAE

Galium aparine L.

T scap - Eurasiat.

Galium spurium L.

T scap - Eurasiat.

Rubia peregrina L. subsp. peregrina

P lian - Steno-Medit.-Macarones.

Sherardia arvensis L.

T scap - Subcosmop.

GentianACEAE

Centaurium pulchellum (Sw.) Druce subsp. pulchellum

T scap - Euri-Medit.

\section{ASTERIDI}

\section{UNPLACED}

\section{Boraginales}

BORAGINACEAE (unplaced)

Cerinthe major L. subsp. major

T scap - Steno-Medit.

Cynoglossum creticum Mill. 
H bienn - Euri-Medit.

Echium plantagineum L.

T scap - Euri-Medit.

Heliotropium europaeum L.

T scap - Euri-Medit.-Turan.

Solanales

\section{Convolvulaceae}

Calystegia sepium (L.) R. Br. subsp. sepium H scand - Paleotemp.

Convolvulus althaeoides L.

H scand - Steno-Medit.(baricentro occid.)

Convolvulus arvensis $\mathrm{L}$.

G rhiz - Paleotemp.

SolAnACEAE

Hyoscyamus albus L.

H bienn - Euri-Medit.

\section{Lycium barbarum L.}

\section{Lamiales}

OleaceAe

Olea europea L. var. sylvestris

Brot. P caesp - Steno-Medit. - D

Plantaginaceae

Antirrhinum majus L. subsp. majus

Ch frut - W-Medit. - Nat

Linaria reflexa (L.) Desf. subsp. reflexa $\mathrm{T}$ rept $-\mathrm{SW}$-Medit.

Plantago coronopus L. subsp. coronopus

T scap - Euri-Medit.

Plantago lagopus L. 
T scap - Steno-Medit.

\section{Plantago lanceolata}

L. H ros-Cosmop.

Plantago macrorrhiza Poir.

$\mathrm{H}$ ros - W-Steno-Medit.

Plantago major L. subsp. major

H ros - Subcosmop.

Plantago weldenii Rchb.

T scap - EuriMedit.

SCROPHULARIACEAE

Myoporum insulare R. Br. [CostalongA (2012) esclude Myoporum tenuifolium G. Forst. dalla flora italiana]

P caesp - Australia - Inv

Verbascum sinuatum L.

H bienn - Euri Medit.

LAMIACEAE

Lamium amplexicaule L.

T scap - Paleotemp.

Marrubium alysson L.

H scap - S-Medit. - LC

Marrubium vulgare L.

H scap - Subcosmop.

Salvia verbenaca $L$.

H scap - Medit.-Atl.

Stachys glutinosa L.

Ch frut - N Italian peninsula (TOS); SAR (Corsica)

VERBENACEAE

Verbena officinalis L.

H scap - Cosmop.

\section{ASTERID II}




\section{Asterales}

ASTERACEAE

Anacyclus clavatus (Desf.) Pers.

T scap - Steno-Medit.

Andryala integrifolia $\mathrm{L}$.

T scap - Medit.-Occid.(Euri-)

Artemisia arborescens (Vaill.) L.

NP - S-Medit.

Calendula arvensis (Vaill.) L.

T scap - Euri-Medit.

Carduus argyroa Biv.

T scap - Steno-Medit.

Carduus pycnocephalus L. subsp. pycnocephalus

H bienn - Medit.-Turan.

\section{Carlina racemosa $\mathrm{L}$.}

T scap - SW-Medit.

Carthamus lanatus L. subsp. lanatus

T scap - Euri-Medit.

\section{Centaurea calcitrapa L.}

T scap - Steno-Medit.

Centaurea melitensis L.

T scap - Pantrop. e Subtrop.

Chondrilla juncea $\mathrm{L}$.

H scap - Euri-Medit.-S-Siber.(Subpontico)

Dittrichia graveolens (L.) Greuter

T scap - Medit.-Turan.

Dittrichia viscosa (L.) Greuter subsp. viscosa H scap - Euri-Medit.

Erigeron bonariensis L.

T scap - America tropic. - Inv

Erigeron canadensis L. 
T scap - Nordamer. - Inv

Erigeron sumatrensis Retz.

T scap - America tropic. - Inv

Filago pyramidata L.

T scap - Euri-Medit.

Galactites elegans (All.) Soldano

H bienn - Steno-Medit.

Glebionis coronaria (L.) Spach

T scap - Steno-Medit. - D

Hedypnois rhagadioloides (L.) F.W. Schmidt

T scap - Steno-Medit.

Helichrysum italicum (Roth) G. Don subsp. microphyllum (Willd.) Nyman

Ch suffr - Endem.(EMO)

Helminthotheca echioides (L.) Holub

T scap - Euri-Medit.

Hypochaeris achyrophorus L.

T scap - Steno-Medit.

Hypochaeris glabra L.

T scap - Euri-Medit.

Lactuca saligna L.

T scap - Euri-Medit.-Turan.

\section{Leontodon tuberosus L.}

$\mathrm{H}$ ros - Steno-Medit.

Limbarda crithmoides (L.) Dumort. subsp. crithmoides

Ch suffr - SW-Europ.

Mantisalca duriaei (Spach) Briq. et Cavill

T scap - Steno-Medit.

Matricaria chamomilla L.

T scap - Subcosmop. - Cas

Pallenis spinosa (L.) Cass.

$\mathrm{H}$ bienn - Euri-Medit.

Phagnalon rupestre (L.) DC. subsp. rupestre 
Ch suffr - W e S-Medit.

Phagnalon saxatile (L.) Cass.

Ch suffr - W-Medit.

Podospermum laciniatum (L.) DC.

H bienn - Paleotemp.

Reichardia picroides (L.) Roth

H scap - Steno-Medit.

Scolymus maculatus L.

T scap - S-Medit.

Scorzoneroides muelleri (Sch. Bip.) Greuter \& Talavera subsp. muelleri

T scap - N Italian peninsula (LIG not confirmed); SIC; SAR

Senecio leucanthemifolius Poir. subsp. leucanthemifolius

T scap - Steno-Medit.

Senecio vulgaris L.

T scap - Cosmop.

Sonchus tenerrimus L.

T scap - Steno-Medit.

Symphyotrichum squamatum (Spreng.) G.L. Nesom

H scap - Neotropic. - Inv

Tolpis virgata (Desf.) Bertol. subsp. grandiflora (Ten.) Arcang.

H scap - C Italian peninsula (UMB, ABR); S Italian peninsula (PUG, CAM, BAS, CAL); SIC, SAR

Tripolium pannonicum (Jacq.) Dobrocz. subsp. pannonicum

$\mathrm{H}$ bienn - Eurasiat.

Urospermum dalechampii (L.) F.W. Schmidt

H scap - Euri-Medit.-Centro-Occid.

Urospermum picroides (L.) Scop. ex F.W. Schmidt

T scap - Euri-Medit.

Xanthium strumarium L. subsp. strumarium

T scap - Cosmop.

Dipsacales 


\section{CAPRIFOLIACEAE}

Sixalix atropurpurea (L.) Greuter \& Burdet subsp. grandiflora (Scop.) Soldano \& F. Conti H scap - Steno-Medit.

\section{Apiales}

APIACEAE

Ammi visnaga (L.) Lam.

T scap - Euri-Medit.

Daucus carota L. subsp. carota

H bienn - Subcosmop.

Daucus carota L. subsp. maximus (Desf.) Ball

H bienn - Euri-Medit.

Daucus muricatus (L.) L.

T scap - W-Medit.

Foeniculum vulgare Mill.

H scap - Steno-Medit.

Torilis nodosa (L.) Gaertn.

T scap - Subcosmop. 
Can artificial ecosystems enhance local biodiversity? The case of a constructed wetland in a Mediterranean urban context -Environmental management - GABRIELE DE MARTIS ${ }^{1}$, BONARIA MULAS ${ }^{2}$, VERONICA MALAVASI ${ }^{3}$ \& MICHELA MARIGNANI ${ }^{2}$

\section{Annex II - Complete floristic list with presence in the years}

\section{Environmental Management}

Can artificial ecosystems enhance local biodiversity? The case of a constructed wetland in a Mediterranean urban context

GABRIELE DE MARTIS ', BONARIA MULAS ${ }^{2}$, VERONICA MALAVASI ${ }^{3} \&$ MICHELA MARIGNANI ${ }^{2}$

1 Via Arcuentu 2/A, 09042 Monserrato, (CA), Italy; docdem73@gmail.com

2 Department of Life and Environmental Sciences - Botany and Botanical Garden Division,

University of Cagliari, Italy; mulas.bonaria@gmail.com ; marignani@unica.it

3 Interdepartmental Center of Environmental Science and Engineering (CINSA), University of

Cagliari, Via San Giorgio 12, 09123 Cagliari, Italy; veronica.malavasi@unica.it

Species are listed according to their presence in the years.

\begin{tabular}{|c|c|c|c|c|c|c|c|c|}
\hline TAXA & 2005 & 2006 & 2007 & 2008 & 2009 & 2010 & 2011 & 2013 \\
\hline Erigeron bonariensis L. & 1 & 1 & 1 & 1 & 1 & 1 & 1 & 1 \\
\hline Amaranthus albus L. & 1 & 1 & 1 & 1 & 1 & 1 & 1 & 1 \\
\hline Atriplex halimus L. & 1 & 1 & 1 & 1 & 1 & 1 & 1 & 1 \\
\hline Nicotiana glauca Graham & 1 & 1 & 1 & 1 & 1 & 1 & 1 & 1 \\
\hline Arthrocnemum macrostachyum (Moric.) Moris & 1 & 1 & 1 & 1 & 1 & 1 & 1 & 1 \\
\hline Limonium avei (De Not.) Brullo \& Erben & 1 & 1 & 1 & 1 & 1 & 1 & 1 & 1 \\
\hline Beta vulgaris L. maritima (L.) Arcang. & 1 & 1 & 1 & 1 & 1 & 1 & 1 & 1 \\
\hline Catapodium rigidum (L.) C.E. Hubb. rigidum & 1 & 1 & 1 & 1 & 1 & 1 & 1 & 1 \\
\hline Cynosurus echinatus L. & 1 & 1 & 1 & 1 & 1 & 1 & 1 & 1 \\
\hline Dittrichia viscosa (L.) Greuter viscosa & 1 & 1 & 1 & 1 & 1 & 1 & 1 & 1 \\
\hline Ecballium elaterium (L.) A. Rich. & 1 & 1 & 1 & 1 & 1 & 1 & 1 & 1 \\
\hline Lagurus ovatus L. ovatus & 1 & 1 & 1 & 1 & 1 & 1 & 1 & 1 \\
\hline Plantago coronopus L. coronopus & 1 & 1 & 1 & 1 & 1 & 1 & 1 & 1 \\
\hline Rumex pulcher L. pulcher & 1 & 1 & 1 & 1 & 1 & 1 & 1 & 1 \\
\hline Sarcocornia perennis (Mill.) A.J. Scott & 1 & 1 & 1 & 1 & 1 & 1 & 1 & 1 \\
\hline Trifolium angustifolium L. angustifolium & 1 & 1 & 1 & 1 & 1 & 1 & 1 & 1 \\
\hline Verbascum sinuatum L. & 1 & 1 & 1 & 1 & 1 & 1 & 1 & 1 \\
\hline Anacyclus clavatus (Desf.) Pers. & 1 & 1 & 1 & 1 & 1 & 1 & 1 & 1 \\
\hline Euphorbia terracina L. & 1 & 1 & 1 & 1 & 1 & 1 & 1 & 1 \\
\hline Glebionis coronaria (L.) Spach & 1 & 1 & 1 & 1 & 1 & 1 & 1 & 1 \\
\hline
\end{tabular}


Can artificial ecosystems enhance local biodiversity? The case of a constructed wetland in a Mediterranean urban context -Environmental management - GABRIELE DE MARTIS ${ }^{1}$, BONARIA MULAS ${ }^{2}$, VERONICA MALAVASI ${ }^{3}$ \& MICHELA MARIGNANI ${ }^{2}$

\begin{tabular}{|c|c|c|c|c|c|c|c|c|}
\hline Hedypnois rhagadioloides (L.) F.W. Schmidt & 1 & 1 & 1 & 1 & 1 & 1 & 1 & 1 \\
\hline Lotus ornithopodioides L. & 1 & 1 & 1 & 1 & 1 & 1 & 1 & 1 \\
\hline Plantago lagopus L. & 1 & 1 & 1 & 1 & 1 & 1 & 1 & 1 \\
\hline Senecio leucanthemifolius Poir. leucanthemifolius & 1 & 1 & 1 & 1 & 1 & 1 & 1 & 1 \\
\hline $\begin{array}{l}\text { Sixalix atropurpurea (L.) Greuter \& Burdet grandiflora } \\
\text { (Scop.) Soldano \& F. Conti }\end{array}$ & 1 & 1 & 1 & 1 & 1 & 1 & 1 & 1 \\
\hline Sonchus tenerrimus L. & 1 & 1 & 1 & 1 & 1 & 1 & 1 & 1 \\
\hline Trisetaria panicea (Lam.) Maire & 1 & 1 & 1 & 1 & 1 & 1 & 1 & 1 \\
\hline Dittrichia graveolens (L.) Greuter & 1 & 1 & 1 & 1 & 1 & 1 & 1 & 1 \\
\hline $\begin{array}{l}\text { Piptatherum miliaceum (L.) Coss. thomasii (Duby) } \\
\text { Freitag }\end{array}$ & 1 & 1 & 1 & 1 & 1 & 1 & 1 & 1 \\
\hline Avena barbata Pott ex Link & 1 & 1 & 1 & 1 & 1 & 1 & 1 & 1 \\
\hline Epilobium hirsutum L. & 1 & 1 & 1 & 1 & 1 & 1 & 1 & 1 \\
\hline Trifolium arvense L. arvense & 1 & 1 & 1 & 1 & 1 & 1 & 1 & 1 \\
\hline Trifolium campestre Schreb. & 1 & 1 & 1 & 1 & 1 & 1 & 1 & 1 \\
\hline Tripolium pannonicum (Jacq.) Dobrocz. pannonicum & 1 & 1 & 1 & 1 & 1 & 1 & 1 & 1 \\
\hline Parapholis filiformis (Roth) C.E. Hubb. & 1 & 1 & 1 & 1 & 1 & 1 & 1 & 1 \\
\hline Parapholis incurva (L.) C. E. Hubb. & 1 & 1 & 1 & 1 & 1 & 1 & 1 & 1 \\
\hline Salicornia patula Duval-Jouve & 1 & 1 & 1 & 1 & 1 & 1 & 1 & 1 \\
\hline Hordeum marinum Huds. marinum & 1 & 1 & 1 & 1 & 1 & 1 & 1 & 1 \\
\hline Dysphania ambrosioides (L.) Mosyakin \& Clemants & 1 & 1 & 1 & 1 & 1 & 1 & 1 & 1 \\
\hline Senecio vulgaris $\mathrm{L}$. & 1 & 1 & 1 & 1 & 1 & 1 & 1 & 1 \\
\hline Solanum nigrum L. & 1 & 1 & 1 & 1 & 1 & 1 & 1 & 1 \\
\hline Suaeda maritima (L.) Dumort. & 1 & 1 & 1 & 1 & 1 & 1 & 1 & 1 \\
\hline Suaeda vera J.F. Gmel. & 1 & 1 & 1 & 1 & 1 & 1 & 1 & 1 \\
\hline Cynodon dactylon (L.) Pers. & 1 & 1 & 1 & 1 & 1 & 1 & 1 & 1 \\
\hline Spergularia salina J. \& C. Presl & 1 & 1 & 1 & 1 & 1 & 1 & 1 & 1 \\
\hline Lysimachia arvensis (L.) U. Manns \& Anderb. arvensis & 1 & 1 & 1 & 1 & 1 & 1 & 1 & 1 \\
\hline Chenopodium album L. album & 1 & 1 & 1 & 1 & 1 & 1 & 1 & 1 \\
\hline Daucus carota L. carota & 1 & 1 & 1 & 1 & 1 & 1 & 1 & 1 \\
\hline Phragmites australis (Cav.) Trin. ex Steud. australis & 1 & 1 & 1 & 1 & 1 & 1 & 1 & 1 \\
\hline $\begin{array}{l}\text { Phragmites australis (Cav.) Trin. ex Steud. chrysanthus } \\
\text { (Mabille) Soják }\end{array}$ & 1 & 1 & 1 & 1 & 1 & 1 & 1 & 1 \\
\hline
\end{tabular}


Can artificial ecosystems enhance local biodiversity? The case of a constructed wetland in a Mediterranean urban context -Environmental management - GABRIELE DE MARTIS ${ }^{1}$, BONARIA MULAS ${ }^{2}$, VERONICA MALAVASI ${ }^{3}$ \& MICHELA MARIGNANI ${ }^{2}$

\begin{tabular}{|c|c|c|c|c|c|c|c|c|}
\hline Rumex obtusifolius L. obtusifolius & 1 & 1 & 1 & 1 & 1 & 1 & 1 & 1 \\
\hline Silene gallica L. & 1 & 1 & 1 & 1 & 1 & 1 & 1 & 1 \\
\hline Sonchus oleraceus L. & 1 & 1 & 1 & 1 & 1 & 1 & 1 & 1 \\
\hline Spergularia bocconei (Scheele) Graebn. & 1 & 1 & 1 & 1 & 1 & 1 & 1 & 1 \\
\hline Centaurea melitensis L. & 1 & 1 & 1 & 1 & 1 & 1 & 1 & 1 \\
\hline Symphyotrichum squamatum (Spreng.) G.L. Nesom & 1 & 1 & 1 & 1 & 1 & 1 & 1 & 1 \\
\hline Lolium rigidum Gaudin rigidum & 1 & 1 & 1 & 1 & 1 & 1 & 1 & 1 \\
\hline Polypogon monspeliensis (L.) Desf. & 1 & 1 & 1 & 1 & 1 & 1 & 1 & 1 \\
\hline Sarcocornia fruticosa (L.) A.J. Scott & 1 & 1 & 1 & 1 & 1 & 1 & 1 & 1 \\
\hline Asparagus stipularis Forssk. & 1 & 1 & 1 & 1 & 1 & 1 & 1 & 1 \\
\hline Melilotus siculus (Turra) Steud. & 1 & 1 & 1 & 1 & 1 & 1 & 1 & 1 \\
\hline Melilotus sulcatus Desf. & 1 & 1 & 1 & 1 & 1 & 1 & 1 & 1 \\
\hline Sphenopus divaricatus (Gouan) Rchb. & 1 & 1 & 1 & 1 & 1 & 1 & 1 & 1 \\
\hline Erigeron sumatrensis Retz. & 0 & 1 & 1 & 1 & 1 & 1 & 1 & 1 \\
\hline Limonium dubium (Guss.) Litard. & 0 & 1 & 1 & 1 & 1 & 1 & 1 & 1 \\
\hline Hirschfeldia incana (L.) Lagr.-Foss. incana & 0 & 1 & 1 & 1 & 1 & 1 & 1 & 1 \\
\hline Tamarix parviflora DC. & 0 & 1 & 1 & 1 & 1 & 1 & 1 & 1 \\
\hline Diplotaxis erucoides (L.) DC. erucoides & 0 & 1 & 1 & 1 & 1 & 1 & 1 & 1 \\
\hline Sulla coronaria (L.) Medik. & 0 & 1 & 1 & 1 & 1 & 1 & 1 & 1 \\
\hline Tamarix africana Poir. var. africana & 0 & 1 & 1 & 1 & 1 & 1 & 1 & 1 \\
\hline Erodium cicutarium (L.) L’Hér. & 0 & 1 & 1 & 1 & 1 & 1 & 1 & 1 \\
\hline Limonium virgatum (Willd.) Fourr. & 0 & 1 & 1 & 1 & 1 & 1 & 1 & 1 \\
\hline Plantago weldenii Rchb. & 0 & 1 & 1 & 1 & 1 & 1 & 1 & 1 \\
\hline Polycarpon tetraphyllum (L.) L. tetraphyllum & 0 & 1 & 1 & 1 & 1 & 1 & 1 & 1 \\
\hline Trifolium stellatum L. & 0 & 1 & 1 & 1 & 1 & 1 & 1 & 1 \\
\hline Cerinthe major L. major & 0 & 1 & 1 & 1 & 1 & 1 & 1 & 1 \\
\hline Galactites elegans (All.) Soldano & 0 & 1 & 1 & 1 & 1 & 1 & 1 & 1 \\
\hline Lotus edulis L. & 0 & 1 & 1 & 1 & 1 & 1 & 1 & 1 \\
\hline Malva olbia (L.) Alef. & 0 & 1 & 1 & 1 & 1 & 1 & 1 & 1 \\
\hline Reseda alba L. alba & 0 & 1 & 1 & 1 & 1 & 1 & 1 & 1 \\
\hline Scorpiurus muricatus L. & 0 & 1 & 1 & 1 & 1 & 1 & 1 & 1 \\
\hline Sinapis arvensis L. arvensis & 0 & 1 & 1 & 1 & 1 & 1 & 1 & 1 \\
\hline Thapsia garganica L. & 0 & 1 & 1 & 1 & 1 & 1 & 1 & 1 \\
\hline
\end{tabular}


Can artificial ecosystems enhance local biodiversity? The case of a constructed wetland in a Mediterranean urban context -Environmental management - GABRIELE DE MARTIS ${ }^{1}$, BONARIA MULAS ${ }^{2}$, VERONICA MALAVASI ${ }^{3}$ \& MICHELA MARIGNANI ${ }^{2}$

\begin{tabular}{|c|c|c|c|c|c|c|c|c|}
\hline Polypogon maritimus Willd. & 0 & 1 & 1 & 1 & 1 & 1 & 1 & 1 \\
\hline Carduus pycnocephalus L. pycnocephalus & 0 & 1 & 1 & 1 & 1 & 1 & 1 & 1 \\
\hline Eruca vesicaria (L.) Cav. & 0 & 1 & 1 & 1 & 1 & 1 & 1 & 1 \\
\hline Convolvulus arvensis L. & 0 & 1 & 1 & 1 & 1 & 1 & 1 & 1 \\
\hline Herniaria hirsuta L. hirsuta & 0 & 1 & 1 & 1 & 1 & 1 & 1 & 1 \\
\hline Sisymbrium irio L. & 0 & 1 & 1 & 1 & 1 & 1 & 1 & 1 \\
\hline Galium spurium L. & 0 & 1 & 1 & 1 & 1 & 1 & 1 & 1 \\
\hline Limbarda crithmoides (L.) Dumort. crithmoides & 0 & 1 & 1 & 1 & 1 & 1 & 1 & 1 \\
\hline Atriplex portulacoides L. & 0 & 1 & 1 & 1 & 1 & 1 & 1 & 1 \\
\hline Atriplex prostrata Boucher ex DC. & 0 & 1 & 1 & 1 & 1 & 1 & 1 & 1 \\
\hline Typha angustifolia L. & 0 & 1 & 1 & 1 & 1 & 1 & 1 & 1 \\
\hline Bolboschoenus maritimus (L.) Palla & 0 & 1 & 1 & 1 & 1 & 1 & 1 & 1 \\
\hline Erigeron canadensis L. & 0 & 1 & 1 & 1 & 1 & 1 & 1 & 1 \\
\hline Plantago lanceolata L. & 0 & 1 & 1 & 1 & 1 & 1 & 1 & 1 \\
\hline Stellaria media (L.) Vill. media & 0 & 1 & 1 & 1 & 1 & 1 & 1 & 1 \\
\hline Malva sylvestris L. sylvestris & 0 & 1 & 1 & 1 & 1 & 1 & 1 & 1 \\
\hline Marrubium vulgare L. & 0 & 1 & 1 & 1 & 1 & 1 & 1 & 1 \\
\hline Asphodelus fistulosus L. & 0 & 1 & 1 & 1 & 1 & 1 & 1 & 1 \\
\hline Ononis reclinata L. & 0 & 1 & 1 & 1 & 1 & 1 & 1 & 1 \\
\hline Thymelaea hirsuta (L.) Endl. & 0 & 1 & 1 & 1 & 1 & 1 & 1 & 1 \\
\hline Acacia longifolia (Andrews) Willd. & 0 & 0 & 1 & 1 & 1 & 1 & 1 & 1 \\
\hline Oxalis pes-caprae L. & 0 & 0 & 1 & 1 & 1 & 1 & 1 & 1 \\
\hline Limonium retirameum Greuter \& Burdet retirameum & 0 & 0 & 1 & 1 & 1 & 1 & 1 & 1 \\
\hline $\begin{array}{l}\text { Euphorbia pithyusa L. cupanii (Guss. ex Bertol.) Radcl.- } \\
\text { Sm. }\end{array}$ & 0 & 0 & 1 & 1 & 1 & 1 & 1 & 1 \\
\hline Antirrhinum majus L. majus & 0 & 0 & 1 & 1 & 1 & 1 & 1 & 1 \\
\hline Calicotome villosa (Poir.) Link & 0 & 0 & 1 & 1 & 1 & 1 & 1 & 1 \\
\hline Carduus argyroa Biv. & 0 & 0 & 1 & 1 & 1 & 1 & 1 & 1 \\
\hline Polypogon subspathaceus Req. & 0 & 1 & 1 & 1 & 0 & 1 & 1 & 1 \\
\hline Salix cinerea subsp. oleifolia Macreight & 0 & 0 & 1 & 1 & 1 & 1 & 1 & 1 \\
\hline Lemna minor L. & 0 & 0 & 1 & 1 & 1 & 1 & 1 & 1 \\
\hline Vicia sativa L. nigra (L.) Ehrh. & 0 & 0 & 1 & 1 & 1 & 1 & 1 & 1 \\
\hline Juncus subulatus Forssk. & 0 & 0 & 1 & 1 & 1 & 1 & 1 & 1 \\
\hline
\end{tabular}


Can artificial ecosystems enhance local biodiversity? The case of a constructed wetland in a Mediterranean urban context -Environmental management - GABRIELE DE MARTIS ${ }^{1}$, BONARIA MULAS ${ }^{2}$, VERONICA MALAVASI ${ }^{3}$ \& MICHELA MARIGNANI ${ }^{2}$

\begin{tabular}{|c|c|c|c|c|c|c|c|c|}
\hline Myoporum insulare R. Br. & 0 & 0 & 0 & 1 & 1 & 1 & 1 & 1 \\
\hline Lycium barbarum L. & 0 & 0 & 0 & 1 & 1 & 1 & 1 & 1 \\
\hline Cortaderia selloana (Schult.) Asch. \& Graebn. & 0 & 0 & 0 & 1 & 1 & 1 & 1 & 1 \\
\hline Stachys glutinosa L. & 0 & 0 & 0 & 1 & 1 & 1 & 1 & 1 \\
\hline Papaver rhoeas L. rhoeas & 1 & 1 & 0 & 0 & 0 & 1 & 1 & 1 \\
\hline Carlina racemosa L. & 0 & 0 & 0 & 1 & 1 & 1 & 1 & 1 \\
\hline Salicornia emerici Duval-Jouve & 0 & 1 & 1 & 0 & 0 & 1 & 1 & 1 \\
\hline Bituminaria bituminosa (L.) C.H. Stirt. & 0 & 0 & 0 & 1 & 1 & 1 & 1 & 1 \\
\hline Helminthotheca echioides (L.) Holub & 0 & 0 & 0 & 1 & 1 & 1 & 1 & 1 \\
\hline Juncus acutus L. acutus & 1 & 1 & 0 & 0 & 0 & 1 & 1 & 1 \\
\hline Ononis natrix L. ramosissima (Desf.) Batt. & 0 & 0 & 0 & 1 & 1 & 1 & 1 & 1 \\
\hline Carlina corymbosa L. & 0 & 0 & 0 & 1 & 1 & 1 & 1 & 1 \\
\hline Cistus creticus L. eriocephalus (Viv.) Greuter \& Burdet & 0 & 0 & 0 & 1 & 1 & 1 & 1 & 1 \\
\hline Cistus salviifolius L. & 0 & 0 & 0 & 1 & 1 & 1 & 1 & 1 \\
\hline Cistus monspeliensis L. & 0 & 0 & 0 & 1 & 1 & 1 & 1 & 1 \\
\hline Echium sabulicola Pomel sabulicola & 0 & 1 & 1 & 1 & 1 & 1 & & \\
\hline Geranium rotundifolium L. & 0 & 0 & 1 & 0 & 1 & 1 & 1 & 1 \\
\hline Ruppia marittima L. & 1 & 1 & 1 & 1 & 0 & 0 & 1 & 0 \\
\hline Arundo donax L. & 0 & 0 & 0 & 1 & 1 & 1 & 1 & 1 \\
\hline Cerastium glomeratum Thuill. & 0 & 0 & 0 & 1 & 1 & 1 & 1 & 1 \\
\hline Lemna gibba L. & 1 & 1 & 1 & 1 & 1 & 0 & 0 & 0 \\
\hline Plantago major L. major & 0 & 0 & 0 & 1 & 1 & 1 & 1 & 1 \\
\hline Stuckenia pectinata (L.) Börner & 0 & 0 & 1 & 1 & 1 & 1 & 1 & 0 \\
\hline Rostraria cristata (L.) Tzvelev cristata & 0 & 0 & 0 & 1 & 1 & 1 & 1 & 1 \\
\hline Ricinus communis L. & 0 & 0 & 0 & 1 & 1 & 1 & 1 & 1 \\
\hline Phalaris minor Retz. & 0 & 0 & 0 & 1 & 1 & 1 & 1 & 1 \\
\hline Artemisia arborescens (Vaill.) L. & 0 & 0 & 0 & 1 & 1 & 1 & 1 & 1 \\
\hline Foeniculum vulgare Mill. & 0 & 0 & 0 & 1 & 1 & 1 & 1 & 1 \\
\hline Mesembryanthemum nodiflorum L. & 1 & 1 & 0 & 0 & 0 & 1 & 1 & 1 \\
\hline Anisantha rubens (L.) Nevski & 0 & 0 & 0 & 1 & 1 & 1 & 1 & 1 \\
\hline Frankenia laevis L. laevis & 0 & 0 & 0 & 1 & 1 & 1 & 1 & 1 \\
\hline Diplotaxis tenuifolia (L.) DC. & 0 & 0 & 0 & 1 & 1 & 1 & 1 & 1 \\
\hline Amaranthus blitoides S. Watson & 1 & 1 & 0 & 0 & 0 & 0 & 1 & 1 \\
\hline
\end{tabular}


Can artificial ecosystems enhance local biodiversity? The case of a constructed wetland in a Mediterranean urban context -Environmental management - GABRIELE DE MARTIS ${ }^{1}$, BONARIA MULAS ${ }^{2}$, VERONICA MALAVASI ${ }^{3}$ \& MICHELA MARIGNANI ${ }^{2}$

\begin{tabular}{|c|c|c|c|c|c|c|c|c|}
\hline Linaria reflexa (L.) Desf. reflexa & 0 & 0 & 0 & 0 & 1 & 1 & 1 & 1 \\
\hline Ononis viscosa L. breviflora (DC.) Nyman & 1 & 1 & 0 & 0 & 0 & 0 & 1 & 1 \\
\hline Anisantha madritensis (L.) Nevski & 0 & 0 & 0 & 0 & 1 & 1 & 1 & 1 \\
\hline Calendula arvensis (Vaill.) L. & 0 & 0 & 0 & 0 & 1 & 1 & 1 & 1 \\
\hline Filago pyramidata L. & 1 & 0 & 0 & 0 & 0 & 1 & 1 & 1 \\
\hline Fumaria capreolata L. capreolata & 0 & 0 & 0 & 0 & 1 & 1 & 1 & 1 \\
\hline Hordeum murinum L. leporinum (Link) Arcang. & 0 & 0 & 0 & 0 & 1 & 1 & 1 & 1 \\
\hline Hyoscyamus albus L. & 0 & 1 & 0 & 0 & 0 & 1 & 1 & 1 \\
\hline Medicago rigidula (L.) All. & 1 & 0 & 0 & 0 & 0 & 1 & 1 & 1 \\
\hline Schenkia spicata (L.) G. Mans. & 0 & 1 & 0 & 0 & 0 & 1 & 1 & 1 \\
\hline Trifolium scabrum L. scabrum & 1 & 0 & 0 & 0 & 0 & 1 & 1 & 1 \\
\hline Parietaria judaica L. & 0 & 0 & 0 & 0 & 1 & 1 & 1 & 1 \\
\hline Arisarum vulgare Targ. Tozz. & 0 & 0 & 0 & 0 & 1 & 1 & 1 & 1 \\
\hline Asparagus acutifolius L. & 0 & 0 & 0 & 0 & 1 & 1 & 1 & 1 \\
\hline Lathyrus clymenum L. & 0 & 1 & 0 & 0 & 1 & 1 & 1 & 0 \\
\hline Malva multiflora (Cav.) Soldano, Banfi \& Galasso & 1 & 1 & 0 & 0 & 0 & 0 & 1 & 1 \\
\hline Molineriella minuta (L.) Rouy & 0 & 0 & 0 & 0 & 1 & 1 & 1 & 1 \\
\hline Olea europea L. var. sylvestris Brot. & 0 & 0 & 0 & 0 & 1 & 1 & 1 & 1 \\
\hline Pistacia lentiscus L. & 0 & 0 & 0 & 0 & 1 & 1 & 1 & 1 \\
\hline Stipa capensis Thunb. & 0 & 0 & 0 & 0 & 1 & 1 & 1 & 1 \\
\hline Tolpis virgata (Desf.) Bertol. grandiflora & 0 & 0 & 1 & 0 & 0 & 1 & 1 & 1 \\
\hline Trifolium spumosum L. & 0 & 0 & 0 & 0 & 1 & 1 & 1 & 1 \\
\hline Rubia peregrina L. peregrina & 0 & 0 & 0 & 0 & 1 & 1 & 1 & 1 \\
\hline Astragalus hamosus L. & 0 & 1 & 1 & 0 & 0 & 0 & 1 & 1 \\
\hline Fumaria parviflora Lam. & 0 & 0 & 0 & 0 & 1 & 1 & 1 & 1 \\
\hline Trachynia distachya (L.) Link & 0 & 0 & 0 & 0 & 1 & 1 & 1 & 1 \\
\hline Heliotropium europaeum L. & 1 & 0 & 0 & 0 & 0 & 1 & 1 & 1 \\
\hline Lactuca saligna L. & 0 & 1 & 0 & 1 & 1 & 1 & & \\
\hline Mercurialis annua L. & 0 & 0 & 0 & 0 & 1 & 1 & 1 & 1 \\
\hline Ranunculus sceleratus L. & 1 & 0 & 0 & 0 & 0 & 1 & 1 & 1 \\
\hline Galium aparine L. & 0 & 0 & 0 & 0 & 1 & 1 & 1 & 1 \\
\hline Phleum arenarium L. caesium H. Scholz & 0 & 1 & 0 & 0 & 0 & 1 & 1 & 1 \\
\hline Salvia verbenaca L. & 0 & 0 & 0 & 0 & 1 & 1 & 1 & 1 \\
\hline
\end{tabular}


Can artificial ecosystems enhance local biodiversity? The case of a constructed wetland in a Mediterranean urban context -Environmental management - GABRIELE DE MARTIS ${ }^{1}$, BONARIA MULAS ${ }^{2}$, VERONICA MALAVASI ${ }^{3}$ \& MICHELA MARIGNANI ${ }^{2}$

\begin{tabular}{|c|c|c|c|c|c|c|c|c|}
\hline Cardamine hirsuta L. & 0 & 0 & 0 & 0 & 1 & 1 & 1 & 1 \\
\hline Euphorbia helioscopia L. helioscopia & 0 & 0 & 0 & 0 & 1 & 1 & 1 & 1 \\
\hline Euphorbia peplus L. & 0 & 0 & 0 & 0 & 1 & 1 & 1 & 1 \\
\hline Ochlopoa annua (L.) H. Scholz & 0 & 0 & 0 & 0 & 1 & 1 & 1 & 1 \\
\hline Polygonum aviculare L. aviculare & 1 & 0 & 0 & 0 & 0 & 1 & 1 & 1 \\
\hline Cyperus rotundus L. & 0 & 0 & 0 & 0 & 1 & 1 & 1 & 1 \\
\hline Juncus maritimus Lam. & 0 & 0 & 1 & 1 & 1 & 1 & 0 & 0 \\
\hline Melilotus indicus (L.) All. & 0 & 0 & 0 & 0 & 1 & 1 & 1 & 1 \\
\hline Sonchus asper (L.) Hill asper & 0 & 0 & 0 & 0 & 1 & 1 & 1 & 1 \\
\hline Spergularia rubra (L.) J. \& C. Presl & 1 & 0 & 0 & 0 & 0 & 1 & 1 & 1 \\
\hline Torilis nodosa (L.) Gaertn. & 0 & 0 & 0 & 0 & 1 & 1 & 1 & 1 \\
\hline Trifolium pratense L. pratense & 0 & 0 & 0 & 0 & 1 & 1 & 1 & 1 \\
\hline Urtica urens L. & 0 & 0 & 0 & 0 & 1 & 1 & 1 & 1 \\
\hline Vulpia myuros (L.) C.C. Gmel. & 0 & 0 & 0 & 0 & 1 & 1 & 1 & 1 \\
\hline Anagyris foetida L. & 0 & 0 & 0 & 0 & 1 & 1 & 1 & 1 \\
\hline Marrubium alysson L. & 0 & 0 & 0 & 1 & 1 & 1 & 1 & 0 \\
\hline Daucus muricatus (L.) L. & 0 & 0 & 0 & 0 & 1 & 1 & 1 & 0 \\
\hline Delphinium gracile DC. & 0 & 0 & 0 & 1 & 0 & 1 & 1 & 0 \\
\hline Ammi visnaga (L.) Lam. & 1 & 1 & 1 & 0 & 0 & 0 & 0 & 0 \\
\hline Erodium moschatum (L.) L’Hér. & 0 & 0 & 0 & 0 & 1 & 0 & 1 & 1 \\
\hline Scirpoides holoschoenus (L.) Soják & 0 & 0 & 0 & 0 & 0 & 1 & 1 & 1 \\
\hline Sisymbrium orientale L. orientale & 0 & 1 & 0 & 0 & 0 & 0 & 1 & 1 \\
\hline Trifolium lappaceum L. & 1 & 0 & 0 & 0 & 0 & 1 & 1 & 0 \\
\hline Linum strictum L. strictum & 0 & 0 & 0 & 0 & 0 & 1 & 1 & 1 \\
\hline Moraea sisyrinchium (L.) Ker-Gawl. & 0 & 1 & 0 & 0 & 0 & 0 & 1 & 1 \\
\hline Plantago macrorrhiza Poir. & 0 & 1 & 0 & 0 & 0 & 0 & 1 & 1 \\
\hline Lamarckia aurea (L.) Moench & 0 & 0 & 0 & 0 & 0 & 1 & 1 & 1 \\
\hline Stellaria pallida (Dumort.) Crép. & 0 & 0 & 0 & 0 & 1 & 1 & 1 & 0 \\
\hline Juncus hybridus Brot. & 1 & 1 & 0 & 0 & 0 & 1 & 0 & 0 \\
\hline Oxybasis urbica (L.) S. Fuentes, Uotila \& Borsch & 0 & 1 & 0 & 0 & 0 & 0 & 1 & 1 \\
\hline Geranium molle L. & 0 & 0 & 0 & 0 & 1 & 1 & 1 & 0 \\
\hline Matricaria chamomilla L. & 0 & 0 & 0 & 0 & 1 & 1 & 1 & 0 \\
\hline Sherardia arvensis L. & 0 & 0 & 0 & 0 & 0 & 1 & 1 & 1 \\
\hline
\end{tabular}


Can artificial ecosystems enhance local biodiversity? The case of a constructed wetland in a Mediterranean urban context -Environmental management - GABRIELE DE MARTIS ${ }^{1}$, BONARIA MULAS ${ }^{2}$, VERONICA MALAVASI ${ }^{3}$ \& MICHELA MARIGNANI ${ }^{2}$

\begin{tabular}{|c|c|c|c|c|c|c|c|c|}
\hline Sulla capitata (Desf.) B.H. Choi \& H. Ohashi & 0 & 0 & 1 & 0 & 0 & 1 & 0 & 0 \\
\hline Carthamus lanatus L. lanatus & 1 & 1 & 0 & 0 & 0 & 0 & 0 & 0 \\
\hline Asphodelus ramosus L. ramosus & 0 & 0 & 0 & 0 & 1 & 1 & 0 & 0 \\
\hline Medicago praecox DC. & 0 & 1 & 0 & 0 & 0 & 0 & 0 & 1 \\
\hline Calystegia sepium (L.) R. Br. sepium & 0 & 0 & 0 & 0 & 1 & 1 & 0 & 0 \\
\hline Schoenoplectus tabernaemontani (C.C. Gmel.) Palla & 0 & 1 & 1 & 0 & 0 & 0 & 0 & 0 \\
\hline Zannichellia palustris L. palustris & 1 & 0 & 0 & 1 & 0 & 0 & 0 & 0 \\
\hline Hornungia procumbens (L.) Hayek & 0 & 1 & 0 & 0 & 0 & 1 & 0 & 0 \\
\hline Schoenoplectus lacustris (L.) Palla & 0 & 1 & 1 & 0 & 0 & 0 & 0 & 0 \\
\hline Atriplex patula L. & 0 & 0 & 0 & 0 & 0 & 0 & 1 & 1 \\
\hline Carlina lanata L. & 0 & 0 & 0 & 0 & 0 & 0 & 1 & 1 \\
\hline $\begin{array}{l}\text { Helichrysum italicum (Roth) G. Don subsp. microphyllum } \\
\text { (Willd.) Nyman }\end{array}$ & n0 & 0 & 0 & 0 & 0 & 0 & 1 & 1 \\
\hline Lolium perenne L. & 0 & 0 & 0 & 0 & 0 & 0 & 1 & 1 \\
\hline Urospermum dalechampii (L.) F.W. Schmidt & 0 & 0 & 0 & 0 & 0 & 0 & 1 & 1 \\
\hline Urtica membranacea Poir. ex Savigny & 0 & 0 & 0 & 0 & 0 & 0 & 1 & 1 \\
\hline Papaver setigerum DC. & 0 & 1 & 0 & 0 & 0 & 0 & 0 & 0 \\
\hline Hypochaeris glabra L. & 0 & 1 & 0 & 0 & 0 & 0 & 0 & 0 \\
\hline Sagina apetala Ard. apetala & 0 & 0 & 0 & 0 & 1 & 0 & 0 & 0 \\
\hline Medicago doliata Carmign. & 0 & 1 & 0 & 0 & 0 & 0 & 0 & 0 \\
\hline Triglochin bulbosum L. barrelieri (Loisel.) Rouy & 0 & 1 & 0 & 0 & 0 & 0 & 0 & 0 \\
\hline Cynomorium coccineum L. coccineum & 0 & 1 & 0 & 0 & 0 & 0 & 0 & 0 \\
\hline Papaver hybridum L. & 0 & 1 & 0 & 0 & 0 & 0 & 0 & 0 \\
\hline Lamium amplexicaule L. & 0 & 0 & 0 & 0 & 1 & 0 & 0 & 0 \\
\hline Trifolium resupinatum L. & 1 & 0 & 0 & 0 & 0 & 0 & 0 & 0 \\
\hline Salicornia dolichostachya Moss & 0 & 0 & 1 & 0 & 0 & 0 & 0 & 0 \\
\hline Xanthium strumarium L. strumarium & 1 & 0 & 0 & 0 & 0 & 0 & 0 & 0 \\
\hline Melilotus albus Medik. & 0 & 1 & 0 & 0 & 0 & 0 & 0 & 0 \\
\hline Paspalum distichum L. & 0 & 1 & 0 & 0 & 0 & 0 & 0 & 0 \\
\hline Acacia saligna (Labill.) H.L. Wendl. & 0 & 0 & 0 & 0 & 0 & 0 & 0 & 1 \\
\hline Achnatherum bromoides (L.) P. Beauv. & 0 & 0 & 0 & 0 & 0 & 0 & 0 & 1 \\
\hline Andryala integrifolia L. & 0 & 0 & 0 & 0 & 0 & 0 & 0 & 1 \\
\hline Anisantha sterilis (L.) Nevski & 0 & 0 & 0 & 0 & 0 & 0 & 0 & 1 \\
\hline
\end{tabular}


Can artificial ecosystems enhance local biodiversity? The case of a constructed wetland in a Mediterranean urban context -Environmental management - GABRIELE DE MARTIS ${ }^{1}$, BONARIA MULAS ${ }^{2}$, VERONICA MALAVASI ${ }^{3}$ \& MICHELA MARIGNANI ${ }^{2}$

\begin{tabular}{|c|c|c|c|c|c|c|c|c|}
\hline Ballota nigra L. subsp. uncinata (Fiori \& Bég.) Patzak & 0 & 0 & 0 & 0 & 0 & 0 & 0 & 1 \\
\hline Bromus hordeaceus L. subsp. hordeaceus & 0 & 0 & 0 & 0 & 0 & 0 & 0 & 1 \\
\hline Centaurea calcitrapa L. & 0 & 0 & 0 & 0 & 0 & 0 & 0 & 1 \\
\hline Centaurium pulchellum (Sw.) Druce subsp. pulchellum & 0 & 0 & 0 & 0 & 0 & 0 & 0 & 1 \\
\hline Chondrilla juncea L. & 0 & 0 & 0 & 0 & 0 & 0 & 0 & 1 \\
\hline Convolvulus althaeoides L. & 0 & 0 & 0 & 0 & 0 & 0 & 0 & 1 \\
\hline Cynoglossum creticum Mill. & 0 & 0 & 0 & 0 & 0 & 0 & 0 & 1 \\
\hline Daucus carota L. subsp. maximus (Desf.) Ball & 0 & 0 & 0 & 0 & 0 & 0 & 0 & 1 \\
\hline Erodium ciconium (L.) L'Hér. & 0 & 0 & 0 & 0 & 0 & 0 & 0 & 1 \\
\hline Hypochaeris achyrophorus L. & 0 & 0 & 0 & 0 & 0 & 0 & 0 & 1 \\
\hline Leontodon tuberosus L. & 0 & 0 & 0 & 0 & 0 & 0 & 0 & 1 \\
\hline Lupinus luteus L. & 0 & 0 & 0 & 0 & 0 & 0 & 0 & 1 \\
\hline Mantisalca duriaei (Spach) Briq. et Cavill & 0 & 0 & 0 & 0 & 0 & 0 & 0 & 1 \\
\hline Melica ciliata L. subsp. magnolii (Gren \& Godr.) Husn. & 0 & 0 & 0 & 0 & 0 & 0 & 0 & 1 \\
\hline Pallenis spinosa (L.) Cass. & 0 & 0 & 0 & 0 & 0 & 0 & 0 & 1 \\
\hline Petrorhagia velutina (Guss.) P. W. Ball \& Heywood & 0 & 0 & 0 & 0 & 0 & 0 & 0 & 1 \\
\hline Phagnalon rupestre (L.) DC. subsp. rupestre & 0 & 0 & 0 & 0 & 0 & 0 & 0 & 1 \\
\hline Phagnalon saxatile (L.) Cass. & 0 & 0 & 0 & 0 & 0 & 0 & 0 & 1 \\
\hline Podospermum laciniatum (L.) DC. & 0 & 0 & 0 & 0 & 0 & 0 & 0 & 1 \\
\hline Reichardia picroides (L.) Roth & 0 & 0 & 0 & 0 & 0 & 0 & 0 & 1 \\
\hline Rostraria hispida (Savi) Doğan & 0 & 0 & 0 & 0 & 0 & 0 & 0 & 1 \\
\hline Scolymus maculatus L. & 0 & 0 & 0 & 0 & 0 & 0 & 0 & 1 \\
\hline $\begin{array}{l}\text { Scorzoneroides muelleri (Sch. Bip.) Greuter \& } \\
\text { Talaverasubsp. muelleri }\end{array}$ & 0 & 0 & 0 & 0 & 0 & 0 & 0 & 1 \\
\hline Tamarix arborea Ehrenb. ex Bunge & 0 & 0 & 0 & 0 & 0 & 0 & 0 & 1 \\
\hline Tamarix canariensis Willd. & 0 & 0 & 0 & 0 & 0 & 0 & 0 & 1 \\
\hline Urospermum picroides (L.) Scop. ex F.W. Schmidt & 0 & 0 & 0 & 0 & 0 & 0 & 0 & 1 \\
\hline Verbena officinalis L. & 0 & 0 & 0 & 0 & 0 & 0 & 0 & 1 \\
\hline Vulpia geniculata (L.) Link. & 0 & 0 & 0 & 0 & 0 & 0 & 0 & 1 \\
\hline Washingtonia filifera (Lindl.) H. Wendl. & 0 & 0 & 0 & 0 & 0 & 0 & 0 & 1 \\
\hline
\end{tabular}

